\title{
DEVELOPMENT OF IMPROVED GASKETS, SEALANTS AND CABLES FOR USE IN GEOTHERMAL WELL LOGGING EQUIPMENT
}

OCTOBER 1978

AEROSPACE GROUPS

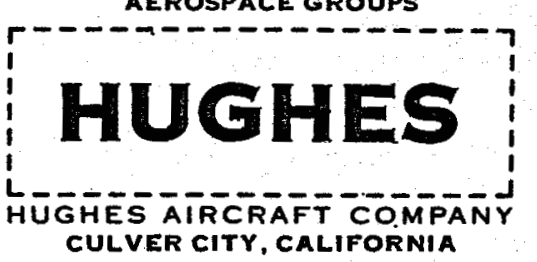




\section{DISCLAIMER}

This report was prepared as an account of work sponsored by an agency of the United States Government. Neither the United States Government nor any agency Thereof, nor any of their employees, makes any warranty, express or implied, or assumes any legal liability or responsibility for the accuracy, completeness, or usefulness of any information, apparatus, product, or process disclosed, or represents that its use would not infringe privately owned rights. Reference herein to any specific commercial product, process, or service by trade name, trademark, manufacturer, or otherwise does not necessarily constitute or imply its endorsement, recommendation, or favoring by the United States Government or any agency thereof. The views and opinions of authors expressed herein do not necessarily state or reflect those of the United States Government or any agency thereof. 


\section{DISCLAIMER}

Portions of this document may be illegible in electronic image products. Images are produced from the best available original document. 
FINAL SUMMARY REPORT

Contract EG-17-C-03-1325

\author{
DEVELOPMENT OF IMPROVED GASKETS, SEALANTS \\ AND CABLES FOR USE IN GEOTHERMAL \\ WEIL LOGGING EQUIPMENT
}
S. Schwartz
D. Basiulis
R. Leyden
A. Landis

October 1978 


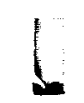

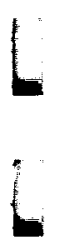

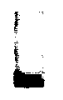

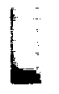

5

$=$

5
5
5

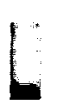

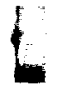

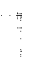

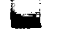

5 
CONTENTS

I. ABSTRACT .......................... 1

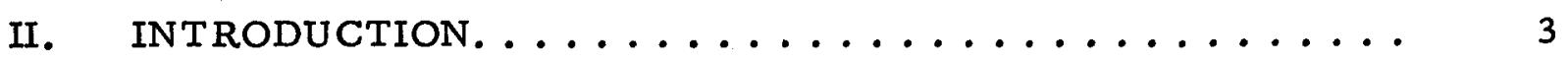

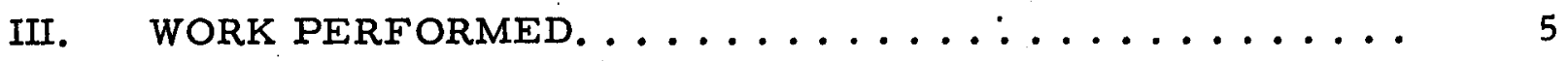

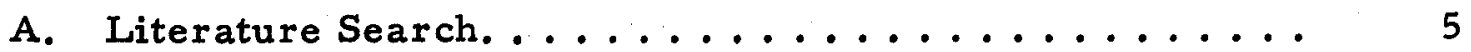

B. Carborane-Siloxane Polymers ................ 5

C. Hydrolytic Stability Tests .................. 18

D. Fluoroalkylene-Siloxane Elastomer............ 23

E. Perfluoroalkylene Oxide Elastomer............. 27

1. Precursor Polymerization.............. 27

a. Benzene Condensation Reactions.......... 29

b. Ethynylbenzamide Terminations .......... 31

c. Ethynylbenzoyl Terminations ........... 32

2. Precursor Copolymerization ............ 33

a. Phenylene Oxides Copolymerizations ........ 33

b. Linear Polyphenylene Copolymers......... 35

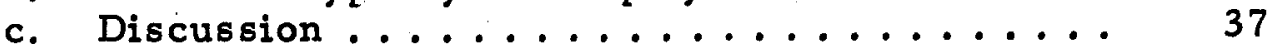

d. Diphenyl Butadiyne Polymerization ........ 41

IV. CONCLUSIONS. ................... 43

v. RECOMMENDATIONS ................. 45

vI. REFERENCES ................... 47

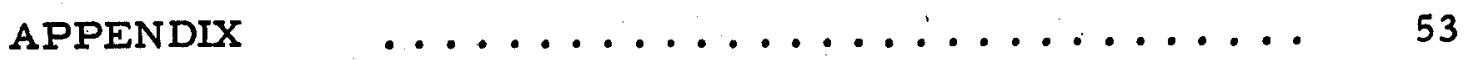


1 Rubber Laboratory Micromill ................. 6

2 DSC on Formulation Number 2 (MgO Filler) . . . . . . . . 11

3 DSC on Plastic Material .................... 12

4 TGA on Formulation Number 2 (Expanded Scale) . . . . . . 13

5 TGA of Ryton (Polyphenylene Sulfide). . . . . . . . . . . 14

6 Hardness. Changes in Carborane-Siloxane Buttons During Postcure ...................... 17

7 Decremental Thickness Changes in Carborane-Siloxane Buttons During Postcure .................. 17

8 Initial Hydrolysis Equipment ................. 19

9 Improved Hydrolysis Equipment ................ 21

10 Hydrolysis Test Sample Ampoule ................ 22

11 Infrared Spectrum of Compound XI ............. 38

12 Infrared Spectrum of Compound XIV .............. 40

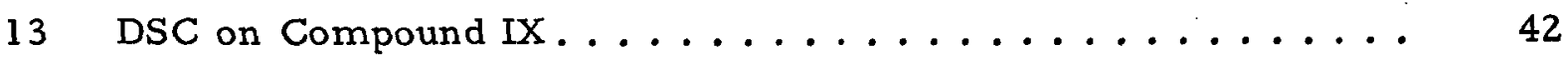

I Carborane-Siloxane Formulation Data . ...........

II Initial Compression Set Tests................

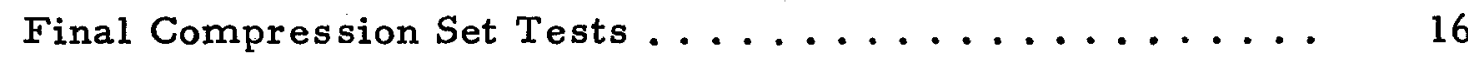




\section{ABSTRACT}

This report describes the work conducted for the Department of Energy on the investigation of materials which could be used for fabricating elastomeric seals for geothermal well logging equipment. The seals were to be made either from a methylphenylcarborane-siloxane base gum stock, or from new fluoroelastomer compounds synthesized at Hughes Aircraft Company.

A literature search was made to obtain data on carborane-siloxane polymers, synthesis routes for fluorinated elastomers and high temperature hydrolytic stability tests of elastomers. Information was obtained on the first two topics, but very little was available on hydrolysis testing.

A number of compounds, based on carborane-siloxane, were formulated and cured. Compression set, hardness and shrinkage tests with post cure variations were made on the most promising formulations. A simple hydrolytic stability test at $275^{\circ} \mathrm{C}\left(525^{\circ} \mathrm{F}\right)$ and 830 psi was developed which indicated that both the carborane and siloxane bonds were easily broken after short exposure periods. Thermodynamic calculations indicated that this result could be expected. Because of the agreement between empirical and theoretical data, work on the carborane-siloxanes was discontinued after approximately the first year.

A second elastomeric material, based on a fluoroalkylated siloxane, was synthesized. A gum stock was prepared and subjected to the hydrolytic stability test. Extensive deterioration was observed after a short period of time. Since this compound had a siloxane backbone, analogous to that of the carborane-siloxane which was found previously to be unstable, work on this polymer was discontinued. 
Synthesis efforts to produce a highly fluorinated elastomer based on perfluorolkylene oxide were continued through the entire program. The first such compound produced (an acetylene-terminated aromatic amide) showed poor hydrolytic stability. A very small quantity of an acetyleneterminated aromatic ketone, derived from the basic perfluoroalkylene oxide elastomer gum, showed promising results in a short-time hydrolytic stability test. However, this material was impossible to produce in large enough quantities to compound into standard test samples. A number of other. attempts were made to form an elastomer based on the perfluoroalkylene oxide. These included copolymerization with pentaphenylene oxide, and a phenylene sulfide polymerization. None of these routes produced a satisfactory elastomer. 


\section{INTRODUCTION}

This report summarizes the work performed by Hughes Aircraft Company on DOE contract EG-17-C-03-1325 during the period of 1 January 1977 to 29 September 1978. The objective of the project during this time period was to investigate materials and techniques which would be the basis for the formulation of elastomeric seals for use in geothermal well logging equipment. Specifically, the elastomers would have to withstand, without significant deterioration, temperatures of $275^{\circ} \mathrm{C}\left(525^{\circ} \mathrm{C}\right)$ or higher in a high pressure humidity environment. The major emphasis of the project was to be directed towards the development of elastomeric compounds formulated from two base polymers: (a) methylphenylcarborane-siloxane, obtained from the Union Carbide Company, and (b) a perfluoro elastomer to be synthesized at Hughes Aircraft Company.

With the successful development of either of these compounds, O-ring type seals, cable terminations and small lengths of insulated cable were to be fabricated. 
W

1

$\rightarrow$

i

1

5

1

6

1

6

6

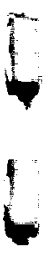

L

6 


\section{WORK PERFORMED}

\section{A. LITERATURE SEARCH}

During the period in which materials were ordered, but not yet received, a literature search was made to uncover information which might aid the synthesis approach and produce any data relating to compounding of either of these materials. The search was made using the computer facilities of the Defense Documentation Center and covered the period from 1952 to 1977. NASA documentation from 1962 to 1977 was also searched. Both of these searches were specifically on fluoroelastomers. A third literature search was made somewhat later in the program using the computer facilities of Wesrac (NASA Industrial Application Center) at the University of Southern California. This search was specifically directed at information on high temperature hydrolysis tests of elastomers. The search covered NASA Publications, Chemical Abstracts, NTIS, and Engineering Index. In addition manual searches were made in "Rubber Chemistry" and "Rubber Chemistry and Technology" at UCLA and USC libraries. The net result of the searches, which included hundreds of references, were several good references on synthesis techniques, descriptions of new rubber compounds (fluoroelastomers and silicones) and conventional tests of fluoroelastomers. Very little information was obtained on hydrolysis tests, except in several Du Pont papers. Only the most pertinent of these references are included in this report in Section VI, References.

\section{B. CARBORANE-SILOXANE POLYMERS}

Because of the very high cost of the carborane-siloxane polymer $(\approx 4000$ per $1 b)$ only a very small amount $(100 \mathrm{gm})$ was ordered. It was 
procured as a millable gum stock. In order to do standard rubber formulating, in which the gum was mixed with the catalyst, the filler, the stabilizer, etc., an extremely small mill was procured. With this equipment, known as a Micromill, it was possible to prepare well milled 3-4 gm formulations using as little as $2 \mathrm{gm}$ of the base polymer. This mill is shown in Figure 1. A small mold was also made so that test "buttons" $1 / 4$ in. diameter $\times 1 / 8$ in. high could be molded. Each button took approximately $0.3 \mathrm{gm}$ of compound. A small formulation of $3-4 \mathrm{gm}$ therefore, could be used to mold 10 to 12 buttons. While it was not possible to run conventional tensile and elongation tests on the buttons, it was possible to determine hardness changes as a result of thermal aging. Compression set tests could be run, using miniature compression set fixtures, and standard thermo-mechanical analysis tests (TMA), thermo-gravimetric analysis tests (TGA), and differential scanning calorimetry tests (DSC) could also be run. Thus a considerable amount of information could be obtained from the small buttons.

Late $r$ in the program, when promising formulations were developed, another small mold was prepared so that $1-1 / 2 \times 3 / 8 \times 1 / 8$ in. "slabs" could be prepared. A miniature tensile specimen die was also built so that tensileelongation samples could be stamped out.

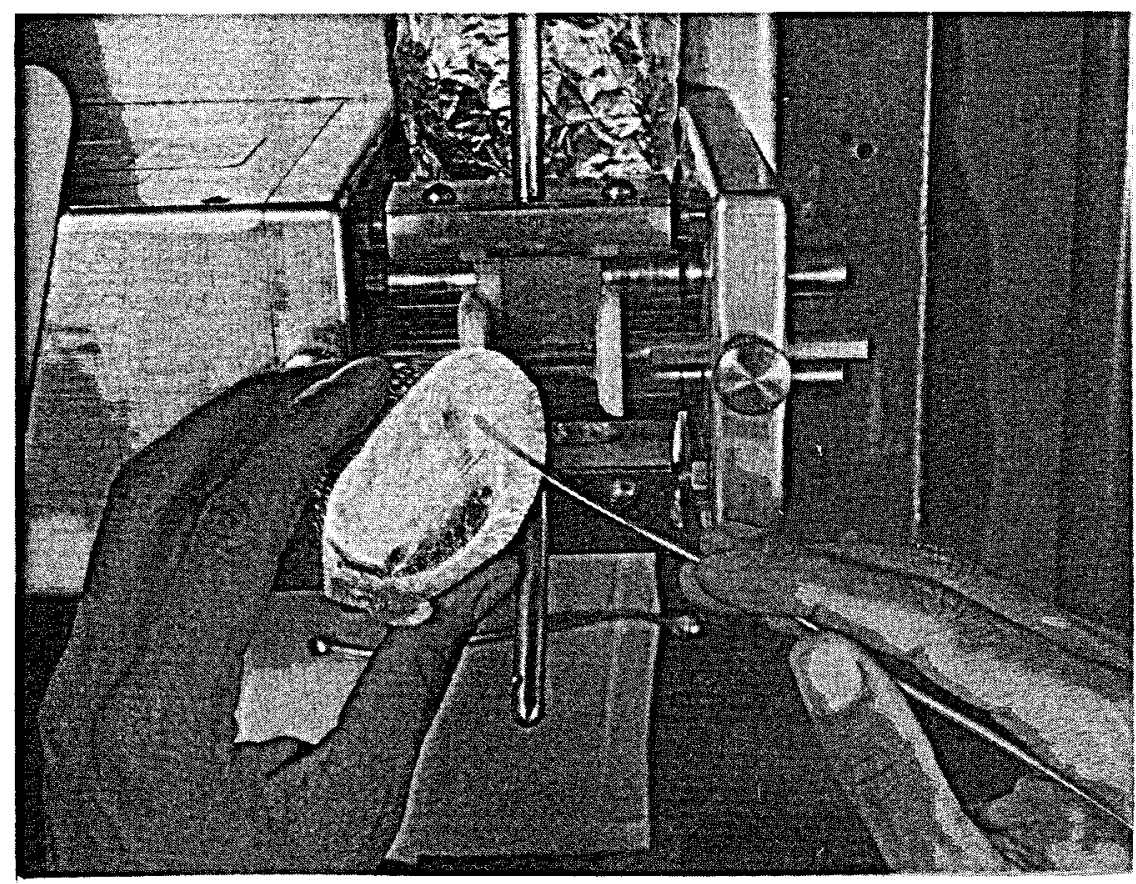

Figure 1. Rubber Laboratory Micromill. 
A number of formulations were made based mainly on the use of magnesium oxide and an activated silica, Tullanox 500, as the filler. The catalysts used were Vulcup 40KE, bis(t-butylperoxyisopropyl)benzene, and Varox, 2,5-dimethyl-2,5-bis(t-butylperoxy)hexane, wi th iron oxide as the stabilizer. Variations were made in both the cure cycle and the postcure heat treatment. Table I shows the formulations, and the cure and postcure cycles.

In order to determine the completeness of cure, a DSC (differential scanning calorimeter) test was made on one of the first formulations. It showed no evidence of either an exothermic or endothermic reaction. Since all the compounds were made with substantially the same proportion of curing agent to polymer, it was decided not to run any more DSC tests until the optimum formulation was developed, or near development. Figure 2 shows the DCS curve for formulation \#2. Figure 3 shows a DCS for a material with a pronounced exotherm.

Thermogravimetric analyses, TGA, were run on one sample of compounded material to determine the effect of high temperature on the carboranesiloxane polymer. The TGA test showed a very slight loss of weight, starting at approximately $300^{\circ} \mathrm{C}\left(600^{\circ} \mathrm{F}\right)$. The tests were continued to $800^{\circ} \mathrm{C}$ $\left(1450^{\circ} \mathrm{F}\right)$, over an 80 minute time span. The final weight loss was 3-1/2 percent. No other tests were made since the formulation, \#2, was considered representative of all the formulations, i.e., each formulation contains approximately the same amount of carborane-siloxane, and all the fillers are high temperature resistant inorganic materials. The TGA curve is shown in Figure 4. Figure 5 shows a typical decomposition curve of a 40 percent glass filled, high temperature resistant plastic, polyphenylene sulfide.

Four thermomechanical analyses were conducted on postcured samples using a DuPont \#900 Thermomechanical Analyzer. The results on the first four formulations were inconclusive. Three formulations, initially penetrated 10 percent, showed expansion while incrementally heated, then increased penetration during 2 hours of isothermal heating at $300^{\circ} \mathrm{C}\left(570^{\circ} \mathrm{F}\right)$. Sample \#4, which was much less rubbery than the other samples, showed very little change during the tests. This indicated the value of high filler loading. 
TABLE I. CARBORANE-SILOXANE FORMULATION DATA

\begin{tabular}{|c|c|c|c|c|c|c|c|c|c|c|c|c|c|c|c|c|c|c|}
\hline \multirow[b]{2}{*}{ Formulation } & \multirow[b]{2}{*}{ Date } & \multicolumn{2}{|c|}{ Polymer } & \multicolumn{2}{|c|}{ Reinforcement } & \multicolumn{2}{|c|}{ Stabilizer } & \multicolumn{2}{|c|}{ Cure Agent } & \multicolumn{4}{|c|}{ Cure Schedule } & \multicolumn{2}{|c|}{ Postcure } & \multirow{2}{*}{$\begin{array}{c}\text { Hardnese } \\
\text { Share } \\
\text { A }\end{array}$} & \multirow{2}{*}{$\begin{array}{c}\text { țthickness }_{\text {in. }} \\
\text { the }\end{array}$} & \multirow[b]{2}{*}{ Remarks } \\
\hline & & Type & Parts & Type & Parts & Type & Parts & Type & Part: & Min & ${ }^{\circ} F$ & Min & ${ }^{\circ} F$ & Hr. & ${ }^{\circ} \mathrm{F}$ & & & \\
\hline 1 & $3-17-77$ & $\mathrm{CBS}^{*}$ & 100 & Tullanox & 45 & $\mathrm{Fe}_{2} \mathrm{O}_{3}$ & 3.9 & Vulcup R & 2.5 & 20 & 250 & 20 & 350 & 24 & $450-600$ & 55 & & \\
\hline 2 & $3-17-77$ & CBS & 100 & $\mathrm{MgO}$ & 31.6 & $\mathrm{Fe}_{2} \mathrm{O}_{3}$ & 2.5 & Vulcup R & 1.66 & 20 & 250 & 20 & 350 & 24 & 450.600 & $30-35$ & & Sticky \\
\hline 3 & $3-23.77$ & CBS & 100 & $\mathrm{MgO}$ & 84.8 & $\mathrm{~F}_{2} \mathrm{O}_{3}$ & 2.5 & $\begin{array}{l}\text { Vuleup } \\
40 K E\end{array}$ & 2.5 & 20 & 250 & 20 & 350 & 24 & $450-600$ & $60-62$ & & \\
\hline 4 & $3-23-77$ & CBS & 100 & As bestos & 101.2 & $\mathrm{Fe}_{2} \mathrm{O}_{3}$ & 2.5 & $\begin{array}{l}\text { Vulcup } \\
\text { 40KE }\end{array}$ & 2.5 & 20 & 250 & 20 & 350 & 24 & $450-600$ & & & Crumbly \\
\hline 5 & $3-23-77$ & CBS & 100 & $\underset{\text { As bestos }}{\text { Tullanox }}$ & $\begin{array}{r}49.7 \\
9.9\end{array}$ & $\mathrm{Fe}_{2} \mathrm{O}_{3}$ & 2.5 & $\begin{array}{l}\text { Vulcup } \\
40 \mathrm{KE}\end{array}$ & 2,25 & 20 & 250 & 20 & 350 & 24 & $450-600$ & -- & & Crumbly \\
\hline 6 & $3-31-77$ & CBS & 100 & As bestos & 70 & $\mathrm{Fe}_{2} \mathrm{O}_{3}$ & 2.5 & $\begin{array}{l}\text { Vuleup } \\
40 \mathrm{KE}\end{array}$ & 2.5 & 20 & 250 & 20 & 350 & 24 & $450-600$ & $60-65$ & & Crumbly \\
\hline 7 & $\begin{array}{l}4-5-77 \\
\therefore\end{array}$ & $\operatorname{cBS}$ & 100 & $\begin{array}{l}\text { Tullanox } \\
\mathrm{MgO}\end{array}$ & $\begin{array}{l}15.0 \\
15.9\end{array}$ & $\mathrm{Fe}_{2} \mathrm{O}_{3}$ & 2.5 & $\begin{array}{l}\text { Vulcup } \\
\text { 40KE }\end{array}$ & 3.1 & 20 & 250 & 20 & 350 & 24 & 450.600 & $45-50$ & & $\begin{array}{l}\text { Soft and } \\
\text { ottcky }\end{array}$ \\
\hline 8 & $4-5-77$ & CBS & 100 & $\begin{array}{l}\text { Tullanox } \\
\text { Mgo }\end{array}$ & $\begin{array}{l}10 \\
29.2\end{array}$ & $\mathrm{Fe}_{2} \mathrm{O}_{3}$ & 2.5 & $\begin{array}{l}\text { Vulcup } \\
40 \mathrm{KE}\end{array}$ & 2.6 & 20 & 250 & 20 & 350 & 24 & $450-600$ & 50 & & \\
\hline 9 & $4-5-77$ & CBS & 100 & $\begin{array}{l}\text { Tullanox } \\
\text { Mica }\end{array}$ & $\begin{array}{l}10 \\
25.4\end{array}$ & $\mathrm{Fe}_{2} \mathrm{O}_{3}$ & 2.65 & $\begin{array}{l}\text { Vulcup } \\
\text { 40KE }\end{array}$ & & 20 & 250 & 20 & 350 & 24 & $450-600$ & 50 & & \\
\hline 10 & 4-15-77 & CBS & 100 & MgO & 59.8 & $\mathrm{Fe}_{2} \mathrm{O}_{3}$ & 2.67 & $\begin{array}{l}\text { Vulcup } \\
\text { 40KE }\end{array}$ & 2.57 & 20 & 250 & 20 & 350 & 24 & $450-600$ & -. & & \\
\hline 11 & 4-15-77 & CBS & 100 & $\mathrm{MgO}$ & 20.4 & $\mathrm{Fe}_{2} \mathrm{O}_{3}$ & 2.6 & $\begin{array}{l}\text { Vulcup } \\
40 \mathrm{KE}\end{array}$ & 2.5 & 20 & 250 & 20 & 350. & 24 & $450-600$ & -. & . & \\
\hline 12 & $4-15-77$ & CBS & 100 & $\begin{array}{l}\text { MgO } \\
\text { Tullanox }\end{array}$ & $\begin{array}{l}60 \\
20.3\end{array}$ & $\mathrm{Fe}_{2} \mathrm{O}_{3}$ & 2.62 & $\begin{array}{l}\text { Vulcup } \\
40 \mathrm{KE}\end{array}$ & 2.5 & 20 & 250 & 20 & 350 & 24 & $450-600$ & .. & & \\
\hline $13 A-1$ & $5-9-77$ & CBS & 100 & $\begin{array}{l}\text { Tullanox } \\
M g O\end{array}$ & $\begin{array}{l}12.3 \\
30.0\end{array}$ & $\mathrm{Fe}_{2} \mathrm{O}_{3}$ & 2.3 & $\begin{array}{l}\text { Vulcup } \\
40 \mathrm{KE}\end{array}$ & 2.3 & 20 & 250 & 20 & 350 & $\begin{array}{l}8 \\
8\end{array}$ & $\begin{array}{l}450 \\
525\end{array}$ & 64 & & \\
\hline $13 A-2$ & $5-9-77$ & CBS & 100 & $\begin{array}{l}\text { Tullanox } \\
\mathrm{MgO}_{\mathrm{g}}\end{array}$ & $\begin{array}{l}12.3 \\
30.3\end{array}$ & $\mathrm{Fe}_{2} \mathrm{O}_{3}$ & 3.3 & $\begin{array}{l}\text { Vulcup } \\
40 \mathrm{KE}\end{array}$ & 2.3 & 120 & 300 & & & $\begin{array}{l}8 \\
8\end{array}$ & $\begin{array}{l}450 \\
525\end{array}$ & 64 & & \\
\hline $13 A-3$ & $5-31-77$ & CBS & 100 & $\begin{array}{l}\text { Tullanox } \\
\mathrm{MgO}\end{array}$ & $\begin{array}{l}12.3 \\
30.0\end{array}$ & $\mathrm{Fe}_{2} \mathrm{O}_{3}$ & 3.3 & $\begin{array}{l}\text { Vulcup } \\
40 \mathrm{KE}\end{array}$ & 3.3 & 120 & 300 & & & $\begin{array}{l}8 \\
8\end{array}$ & $\begin{array}{l}450 \\
525\end{array}$ & $54-55$ & & \\
\hline $13 B-1$ & $5-9-77$ & CBS & 100 & $\begin{array}{l}\text { Tullanox } \\
\mathrm{MgO}\end{array}$ & $\begin{array}{l}12.3 \\
30.0\end{array}$ & $\mathrm{Fe}_{2} \mathrm{O}_{3}$ & 3.6 & $\begin{array}{l}\text { Vulcup } \\
40 \mathrm{KE}\end{array}$ & 1.2 & 20 & 250 & 20 & 350 & $\begin{array}{l}8 \\
8\end{array}$ & $\begin{array}{l}450 \\
525\end{array}$ & 40 & & \\
\hline $13 \mathrm{~B}-2$ & $5-9-77$ & CBS & 100 & $\begin{array}{l}\text { Tullanox } \\
\mathrm{M}_{\mathrm{B}}\end{array}$ & $\begin{array}{l}12.3 \\
30.0\end{array}$ & $\mathrm{Fe}_{2} \mathrm{O}_{3}$ & 3.6 & $\begin{array}{l}\text { vulcup } \\
40 \mathrm{KE}\end{array}$ & 1.2 & 120 & 300 & & & $\begin{array}{l}8 \\
8\end{array}$ & $\begin{array}{l}450 \\
525\end{array}$ & 38 & & \\
\hline $13 B-3$ & $5-31-77$ & CBS & 100 & $\begin{array}{l}\text { Tullanox } \\
\mathrm{MgO}\end{array}$ & $\begin{array}{l}12.3 \\
30.1\end{array}$ & $\mathrm{~F}_{2} \mathrm{O}_{3}$ & 6.6 & $\begin{array}{l}\text { Vuleup } \\
40 \mathrm{KE}\end{array}$ & 4.2 & 120 & 300 & & & $\begin{array}{l}8 \\
8\end{array}$ & $\begin{array}{l}450 \\
525\end{array}$ & 56 & & . \\
\hline $14 A-1$ & $5-9-77$ & CBS & 100 & $\begin{array}{l}\text { Tullanox } \\
\text { MgO }\end{array}$ & $30^{12.5}$ & $\mathrm{Fe}_{2} \mathrm{O}_{3}$ & 5.0 & $\begin{array}{l}\text { Vulcup } \\
40 \mathrm{KE}\end{array}$ & 5.0 & 20 & 250 & 20 & 350 & 8 & $\begin{array}{l}450 \\
525\end{array}$ & 61 & . & - \\
\hline $14 \mathrm{~A}-2$ & $5-9-77$ & CBS & 100 & $\begin{array}{l}\text { Tullanox } \\
\mathrm{MgO}\end{array}$ & ${ }_{30}^{12.5}$ & $\mathrm{Fe}_{2} \mathrm{O}_{3}$ & 5.0 & $\begin{array}{l}\text { Vulcup } \\
\text { 40KE }\end{array}$ & 5.0 & 120 & 300 & & & $\begin{array}{l}8 \\
8\end{array}$ & $\begin{array}{l}450 \\
525\end{array}$ & 60 & . & 1 \\
\hline $14 A-3$ & $5-31-77$ & CBS & 100 & $\begin{array}{l}\text { Tullanox } \\
\text { MgO }\end{array}$ & ${ }_{30}^{12.5}$ & $\mathrm{~F}_{2} \mathrm{O}_{3}$ & 8.9 & $\begin{array}{l}\text { Vulcup } \\
40 \mathrm{KE}\end{array}$ & 8. 9 & 120 & 300. & & & $\begin{array}{l}8 \\
8\end{array}$ & $\begin{array}{l}450 \\
525\end{array}$ & 65 & & \\
\hline
\end{tabular}

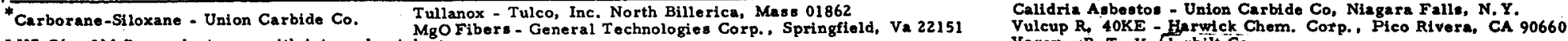
LVS-76 - 3M fluoroelastomer with internal catalyat A29 biepropionitrile astomer 
(Table I, continued)

\begin{tabular}{|c|c|c|c|c|c|c|c|c|c|c|c|c|c|c|c|c|c|c|}
\hline \multirow[b]{2}{*}{ Formulation } & \multirow[b]{2}{*}{ Date } & \multicolumn{2}{|c|}{ Polymor } & \multicolumn{2}{|c|}{ Relinforcement } & \multicolumn{2}{|c|}{ Stabillizer } & \multicolumn{2}{|c|}{ Cure Agent } & \multicolumn{4}{|c|}{ Cure Schedule } & \multicolumn{2}{|c|}{ Postcure } & \multirow{2}{*}{ 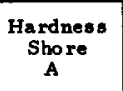 } & \multirow{2}{*}{$\begin{array}{c}\text { Thlcknases } \\
\text { ing }\end{array}$} & \multirow[b]{2}{*}{ Remarka } \\
\hline & & Type & Parto & Type & Parts & Type & Parts & Tppe & Parts & Min & ${ }^{o_{F}}$ & Min & ${ }^{{ }^{*} \mathbf{F}}$ & H. & ${ }^{\circ} F_{F}$ & & & \\
\hline 15 & $6-6-77$ & CBS & 100 & $\begin{array}{l}T_{\text {Mullanox }} \\
\text { MgO }\end{array}$ & $\begin{array}{l}12.5 \\
30\end{array}$ & $\mathrm{Fe}_{2} \mathrm{O}_{3}$ & 5,5 & $\begin{array}{l}\text { A29 bis- } \\
\text { propopio- }\end{array}$ & 3.5 & 120 & 250 & & & ${ }_{8}^{8}$ & $\begin{array}{l}450 \\
525\end{array}$ & No cure. & & \\
\hline $16 \mathrm{~A}$ & 6-7-77 & CBS & 100 & $\begin{array}{l}\text { Tullandx } \\
\text { Mpo }\end{array}$ & ${ }_{35}^{15}$ & $\mathrm{Fe}_{2} \mathrm{O}_{3}$ & 3.75 & 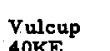 & 3.75 & 30 & 340 & & & 8 & 450 & 50 & & \\
\hline $16 \mathrm{~B}$ & 6-7-77 & CBS & 100 & Tullabox & 26.7 & $\mathrm{Fe}_{2} \mathrm{O}_{3}$ & 3.75 & Yalcup & 3. 75 & ${ }_{30}$ & 340 & & & 8 & $\begin{array}{l}450 \\
452 \\
5\end{array}$ & 59 & & \\
\hline $17 \mathrm{~A}$ & $6-9-77$ & CBS & 100 & $\begin{array}{l}\text { Tullanox } \\
\text { MeO }\end{array}$ & $\begin{array}{l}15 \\
35\end{array}$ & $\mathrm{Fe}_{2} \mathrm{O}_{3}$ & 3.75 & varox & 3.75 & 30 & 340 & & & 8 & 450 & 45 & & \\
\hline 178 & 6-9-77 & CBS & 100 & $\begin{array}{l}\text { Tullanox } \\
\text { MyO }\end{array}$ & $\begin{array}{l}26.7 \\
66.3\end{array}$ & $\mathrm{Fe}_{2} \mathrm{O}_{3}$ & 3.75 & varox & 3. 75 & 30 & 340 & & & 8 & $\begin{array}{l}450 \\
5525 \\
525\end{array}$ & 69 & & \\
\hline 18 & |6-14-77 & CBS & 100 & $\begin{array}{l}\text { Tullanox } \\
\text { MgO }\end{array}$ & $\begin{array}{l}15 \\
35\end{array}$ & $\mathrm{Fe}_{2} \mathrm{O}_{3}$ & 5 & Varox & 5 & 30 & 340 & & & 16 16 & $\begin{array}{l}450 \\
455\end{array}$ & 43 & 0.125 & \\
\hline 19 & ${ }^{6-14-77}$ & CBS & 100 & $\begin{array}{l}\text { Tullanox } \\
\text { MgO }\end{array}$ & ${ }_{35}^{15}$ & $\mathrm{~F}_{2} \mathrm{O}_{3}$ & 10 & Vasox & 10 & ${ }^{30}$ & 340. & & & 㗭 & $\begin{array}{l}450 \\
555 \\
552\end{array}$ & 45 & 0.126 & \\
\hline 20 & 6-14-77 & CBS & 100 & $\begin{array}{l}\text { Tullanox } \\
\text { M\&O }\end{array}$ & $\begin{array}{l}20 \\
45\end{array}$ & $\mathrm{Fe}_{2} \mathrm{O}_{3}$ & 12.5 & varox & 12.5 & 30. & 340 & & & & & 53 & 0.131 & \\
\hline 21 & 6-16-77 & $\mid \begin{array}{c}\text { CBS } \\
\text { IVT-76 }\end{array}$ & 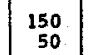 & $\begin{array}{l}\text { Tullanox } \\
\text { MgO }\end{array}$ & $\begin{array}{l}30 \\
70 \\
0\end{array}$ & $\begin{array}{l}\mathrm{F}=2 \mathrm{O}_{3} \\
\mathrm{CaO}\end{array}$ & $\frac{5}{3}$ & varox & 5 & 30 & 340 & & & & & & & No cure \\
\hline 22 & |6-16-77 & 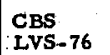 & $\begin{array}{l}100 \\
100\end{array}$ & $\begin{array}{l}\text { Tullabox } \\
\text { MgO }\end{array}$ & $\begin{array}{l}30 \\
70\end{array}$ & 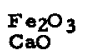 & $\begin{array}{l}3.5 \\
6.0\end{array}$ & varox & 3.5 & 30 & ${ }^{340}$ & & & & & & & No cure \\
\hline 23 & 6-16-77 & 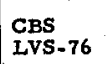 & $\begin{array}{r}50 \\
150\end{array}$ & 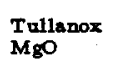 & $\begin{array}{l}30 \\
70\end{array}$ & 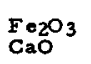 & $\begin{array}{l}2.5 \\
9.0\end{array}$ & va arox & 2.5 & 30 & 34 & & & & & & & No cure \\
\hline 24 & $6-16-77$ & LvS-76 & 200 & $\begin{array}{l}\text { Tullanox } \\
\text { MgO }\end{array}$ & $\mid \begin{array}{c}30 \\
60 \\
60\end{array}$ & cao & 10 & None & & & & & & & & 84 & 0.129 & Cured \\
\hline 25 & |6-17-77 & $\mid \begin{array}{c}\text { CAS } \\
\text { LvS }-76\end{array}$ & 芳50 & $\begin{array}{l}\text { Tullanox } \\
\text { MgO }\end{array}$ & $\mid \begin{array}{c}30 \\
70 \\
0\end{array}$ & $\mathrm{Fe}_{2} \mathrm{O}_{3}$ & 1.5 & varox & 1.5 & & & & & & & & & No cure \\
\hline 26 & 6-17-77 & 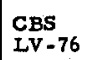 & $\begin{array}{r}50 \\
150\end{array}$ & The & $\begin{array}{l}65^{69} \\
255^{2}\end{array}$ & $\mid \begin{array}{l}\mathrm{Fe}_{2} \mathrm{O}_{3} \mathrm{O}_{3} \\
\mathrm{CaO}^{2}\end{array}$ & $\mid \begin{array}{c}10 \\
5\end{array}$ & & 30 & 340 & & & & & & 45 & 0.1258 & \\
\hline 27 & 6-20-77 & CBS & 100 & 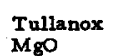 & $\begin{array}{l}10 \\
.30 \\
\end{array}$ & $\mathrm{Fe}_{2} \mathrm{O}_{3}$ & 5 & varox & 5 & & & & & & & 42 & 0.1225 & \\
\hline 28 & $\begin{array}{l}6-20-77 \\
\end{array}$ & CBS & 100 & $\operatorname{M}_{\mathrm{M}_{8 \mathrm{O}}}^{\text {Thlatax }}$ & 12.5 & $\mathrm{Fe}_{2} \mathrm{O}_{3}$ & 3 & 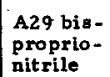 & 30. & 320 & 350 & & & & & & & No cure \\
\hline 29 & 6-27-77 & 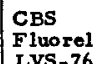 & $\begin{array}{lll}5 & 50 \\
50 & 0 \\
50 & \end{array}$ & $\begin{array}{l}\text { Thllatans } \\
\text { Mglo }\end{array}$ & $\mid \begin{array}{l}15 \\
35\end{array}$ & 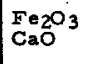 & 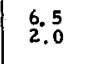 & None & None & $\begin{array}{l}30 \\
90\end{array}$ & $\mid$ & $340^{\circ}$ & & & & & & $\begin{array}{l}\text { Diad not } \\
\text { cure }\end{array}$ \\
\hline 30 & $6-28-77$ & 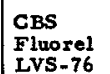 & $\begin{array}{l}75 \\
25 \\
25\end{array}$ & $\underbrace{}_{M_{80}^{\text {Tullanox }}}$ & \begin{tabular}{|l}
15 \\
35
\end{tabular} & $\mathrm{Fe} 2 \mathrm{O}_{3}$ & $\begin{array}{l}6.0 \\
2.0\end{array}$ & None & None & 30 & 60 & $340^{\circ}$ & & & & & & $\begin{array}{l}\text { pid not } \\
\text { curre }\end{array}$ \\
\hline 31 & 7-7-7.-77 & css & 100 & 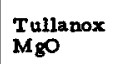 & $\begin{array}{l}15 \\
20\end{array}$ & $\mathrm{Fe}_{2} \mathrm{O}_{3}$ & 5.0 & varox & $\begin{array}{l}2.0 \\
\end{array}$ & 30 & 340 & & & & & 45 & & $\begin{array}{l}\text { Soft and } \\
\text { sticky }\end{array}$ \\
\hline
\end{tabular}


(Table I, concluded)

\begin{tabular}{|c|c|c|c|c|c|c|c|c|c|c|c|c|c|c|c|c|c|c|}
\hline \multirow[b]{2}{*}{ Formulation } & \multirow[b]{2}{*}{ Date } & \multicolumn{2}{|c|}{ Polymex } & \multicolumn{2}{|c|}{ Reinforcement } & \multicolumn{2}{|c|}{ Stabilizer } & \multicolumn{2}{|c|}{ Cure Agent } & \multicolumn{4}{|c|}{ Cure Schedule } & \multicolumn{2}{|c|}{ Postcure } & \multirow{2}{*}{$\begin{array}{c}\text { Hardnese } \\
\text { Shore } \\
\text { A }\end{array}$} & \multirow{2}{*}{$\begin{array}{l}\text { Thickness } \\
\text { in. } \times 10^{-3} \\
\end{array}$} & \multirow[b]{2}{*}{ Remarks } \\
\hline & & Type & Parts & Type & Parts & Type & Parts & Type & Parts & Min & ${ }^{\circ} F$ & Min & ${ }^{\circ} \bar{F}$ & Hr. & ${ }^{\circ} \boldsymbol{F}$ & & & \\
\hline 32 & 7-7-77 & CBS & 100 & $\begin{array}{l}\text { Tullanox } \\
\text { MgO }\end{array}$ & 15 & $\mathrm{Fe}_{2} \mathrm{O}_{3}$ & 2.5 & Varox & 2.5 & 30 & 340 & & I & & & & $40-50$ & Stleky \\
\hline 33 & $8-1-77$ & CBS & 100 & $\begin{array}{l}\text { Tullanox } \\
\text { MgO }^{\text {and }}\end{array}$ & $\begin{array}{l}13,3 \\
31,9\end{array}$ & $\mathrm{Fe}_{2} \mathrm{O}_{3}$ & 8.3 & Valcup & 3.75 & 30 & 340 & & & 48 & $450^{\circ}$ & $70-79$ & 53.3 & \\
\hline 34 & $8-1-77$ & CBS & 100 & $\begin{array}{l}\text { Tullanox } \\
\text { MgO }\end{array}$ & $\begin{array}{l}5.87 \\
14.3\end{array}$ & $\mathrm{Fe}_{2} \mathrm{O}_{3}$ & 12.5 & Varox & 12.5 & 30 & 340 & & & $\begin{array}{l}48 \\
48\end{array}$ & $\begin{array}{l}450 \\
525\end{array}$ & $61-72$ & 52.6 & \\
\hline 35 & $8-9-77$ & CBS & 100 & $\begin{array}{l}\text { Tullanox } \\
\mathrm{MgO}\end{array}$ & $\begin{array}{c}5.87 \\
14.3\end{array}$ & $\mathrm{Fe}_{2} \mathrm{O}_{3}$ & 12.5 & $\begin{array}{l}\text { Vulcup } \\
40 \mathrm{KE}\end{array}$ & 3. 75 & 30 & 340 & & & $\begin{array}{l}48 \\
48\end{array}$ & $\begin{array}{l}450^{\circ} \\
525\end{array}$ & $45-49$ & 42.5 & \\
\hline 36 & $8-9.77$ & $C_{B S}$ & 100 & $\begin{array}{l}\text { Tullanox } \\
\text { MgO }\end{array}$ & 20 & $\mathrm{Fe}_{2} \mathrm{O}_{3}$ & 12.5 & $\begin{array}{l}\text { Vulcup } \\
40 \mathrm{KE}\end{array}$ & 3.75 & 30 & 340 & & & $\begin{array}{l}48 \\
48\end{array}$ & $\begin{array}{l}450 \\
525\end{array}$ & $60-63$ & 48. 2 & \\
\hline 37 & $8-9-77$ & CBS & 100 & $\begin{array}{l}\text { Tullanox } \\
\text { MgQ }\end{array}$ & $\begin{array}{l}20 \\
50\end{array}$ & $\mathrm{Fe}_{2} \mathrm{O}_{3}$ & 12.5 & Varox & 12.5 & 30 & 340 & & & $\begin{array}{r}48 \\
48\end{array}$ & $\begin{array}{l}450 \\
525\end{array}$ & $67-70$ & 56 & \\
\hline
\end{tabular}




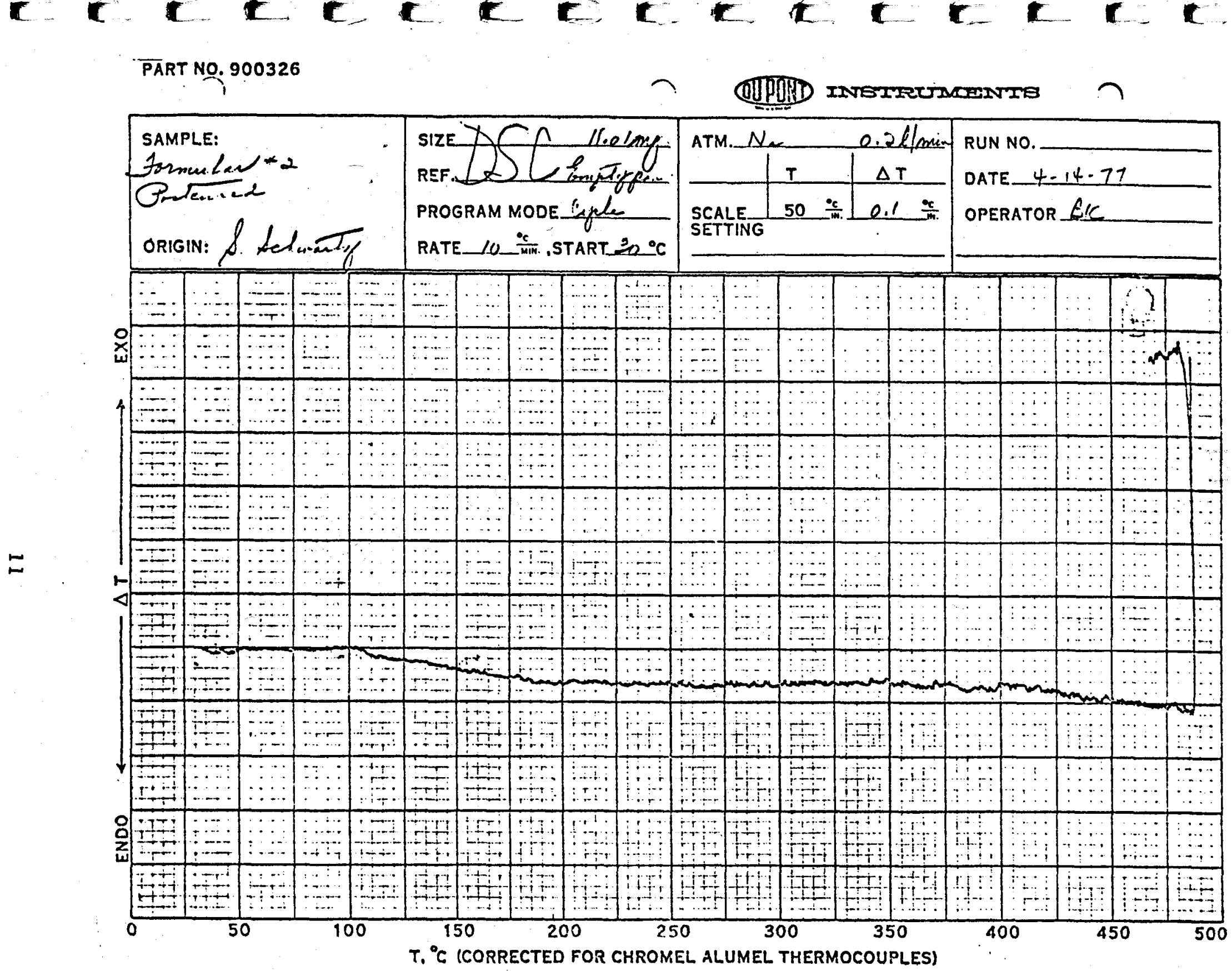

Figure 2. DSC on formulation number 2 ( $\mathrm{MgO}$ filler). 


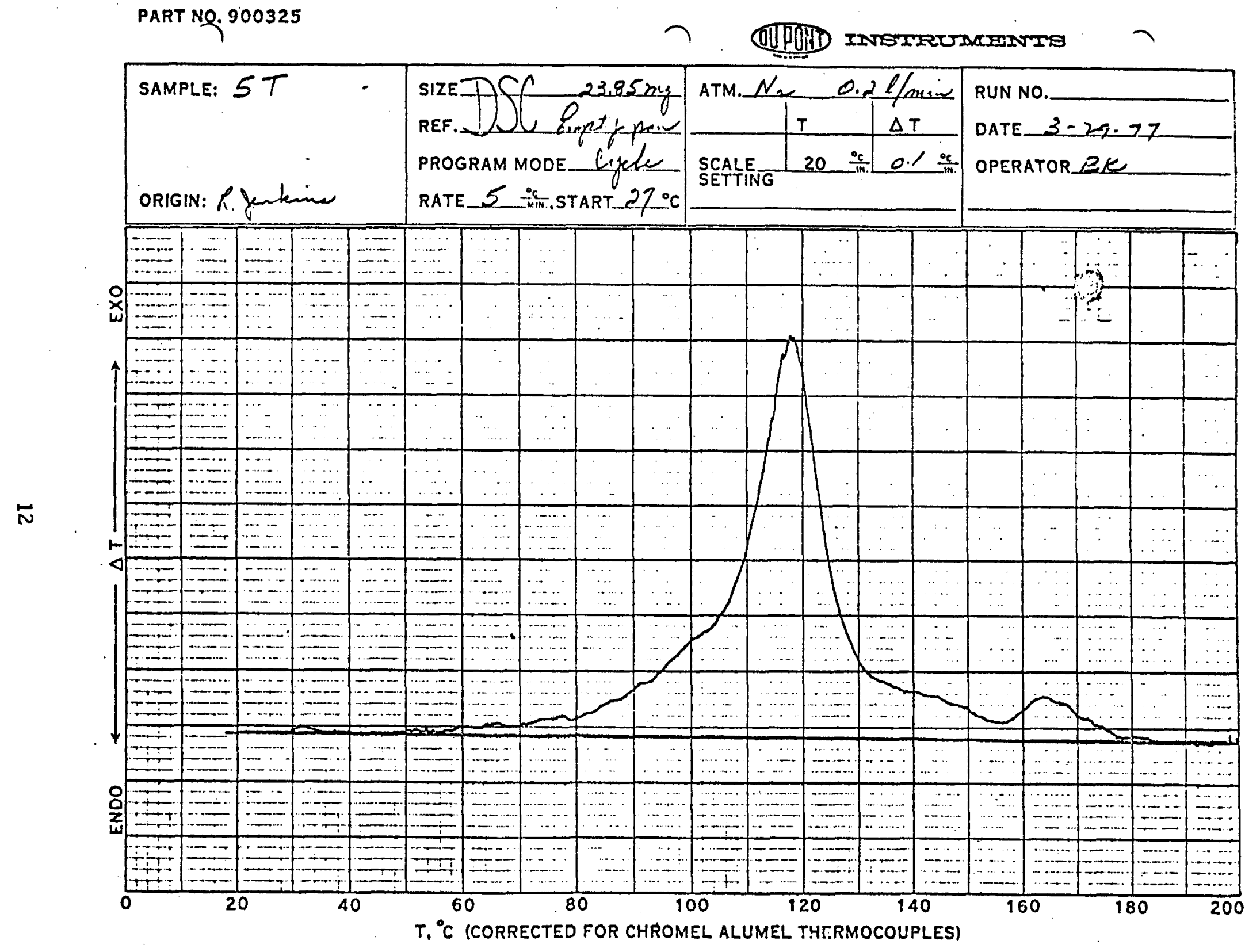

Figure 3. DSC on plastic material. 
PART NO. 950252

-

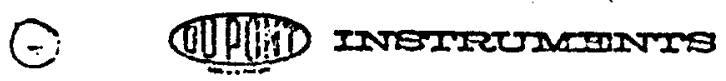

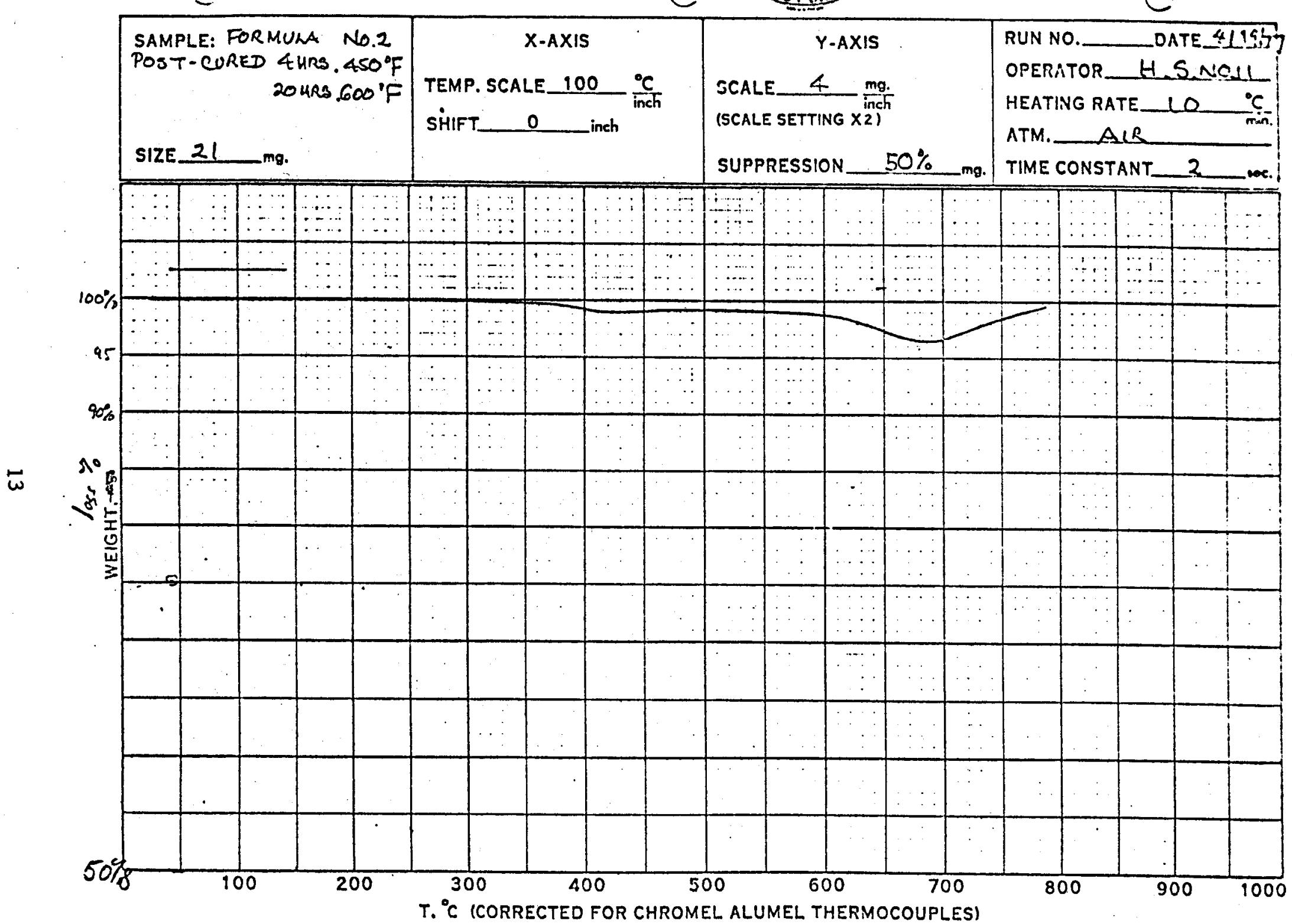

Figure 4. TGA on formulation number 2 (expanded scale). 


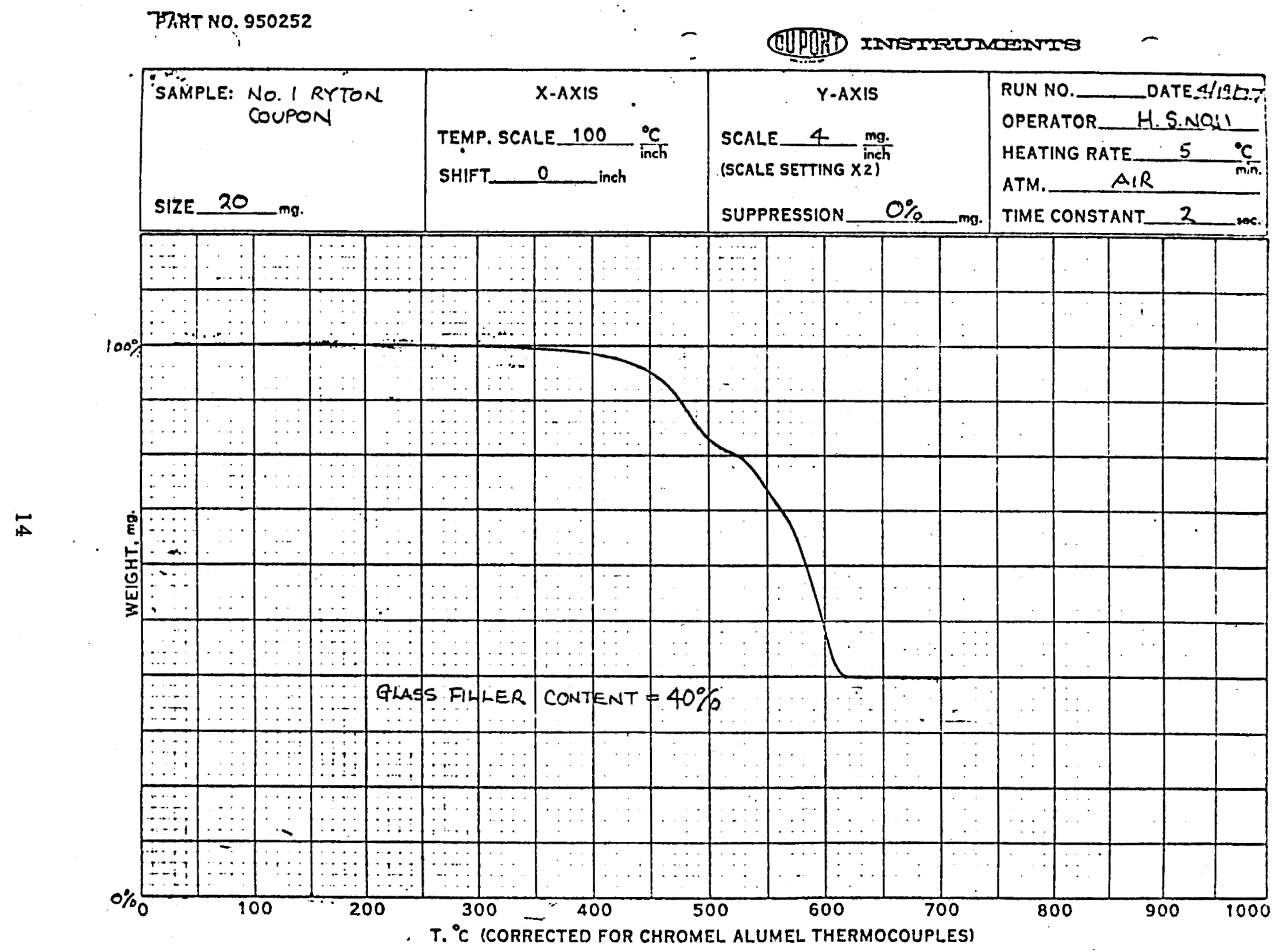

Figure 5. TGA of Ryton (polyphenylene sulfide). 
Compression set tests also were run on the later formulations, but only on the samples postcured at $300^{\circ} \mathrm{C}\left(575^{\circ} \mathrm{F}\right)$. The results of these tests are shown in Table III, along with the curing agent types and amounts, and the filler types and amounts. No appreciable improvement was noted, except that the higher percent of filler was effective in reducing the set in the Vulcup cured material.

An effort was made to optimize the later formulations with regard to hardness and shrinkage changes after prolonged, cumulative, oven aging. The results of these tests are shown in Figures 6 and 7 . Figure 6 shows the changes in Shore hardness of various buttons made from some of the formulations shown in Table I. Figure 7 shows the average decremental changes in thickness (due to shrinkage) of each formulation. It should be noted that on each plot two sets of data are shown for each formulation. The solid line in each case represents the average changes in the button samples after 48 hours at $230^{\circ} \mathrm{C}\left(450^{\circ} \mathrm{F}\right)$, followed by up to 215 hours at $275^{\circ} \mathrm{C}\left(525^{\circ} \mathrm{F}\right)$. The dashed lines, starting after 48 hours at $275^{\circ} \mathrm{C}\left(525^{\circ} \mathrm{F}\right)$, show the changes in other buttons after 48 hours at $300^{\circ} \mathrm{C}\left(575^{\circ} \mathrm{F}\right)$ for two buttons of each group.

TABLE III. FINAL COMPRESSION SET TESTS

\begin{tabular}{|c|c|c|c|c|c|c|c|}
\hline \multirow[b]{2}{*}{ Formulation } & \multicolumn{2}{|c|}{ Curing Agent } & \multicolumn{2}{|c|}{ Filler } & \multicolumn{2}{|c|}{$\begin{array}{c}\text { Final } \\
\text { Hardness }\end{array}$} & \multirow{2}{*}{$\begin{array}{l}\text { Comp. } \\
\text { Set. } \%\end{array}$} \\
\hline & Type & $\% *$ & Type & $\%$ & Cure & Cure & \\
\hline 33 & $\begin{array}{l}\text { Vulcup } \\
40 \mathrm{KE}\end{array}$ & 3.75 & $\begin{array}{l}\text { Tullanox } \\
\text { MgO }\end{array}$ & $\begin{array}{l}13 \\
32\end{array}$ & 70 & 79 & $93-100$ \\
\hline 34 & Varox & 12.5 & $\begin{array}{l}\text { Tullanox } \\
\text { MgO }\end{array}$ & $\begin{array}{l}13 \\
12\end{array}$ & 61 & 82 & 98 \\
\hline 35 & $\begin{array}{l}\text { Vulcup } \\
40 \mathrm{KE}\end{array}$ & 3.75 & $\begin{array}{l}\text { Tullanox } \\
\text { MgO }\end{array}$ & $\begin{array}{l}5.87 \\
14.3\end{array}$ & 45 & 49 & 122 \\
\hline 36 & $\begin{array}{l}\text { Vulcup } \\
40 \mathrm{KE}\end{array}$ & 3.75 & $\begin{array}{l}\text { Tullanox } \\
\text { MgO }\end{array}$ & $\begin{array}{l}20 \\
50\end{array}$ & 60 & 63 & 81 \\
\hline 37 & Varox & 12.5 & Tullanox & $\begin{array}{l}20 \\
50\end{array}$ & 67 & 70 & 100 \\
\hline
\end{tabular}




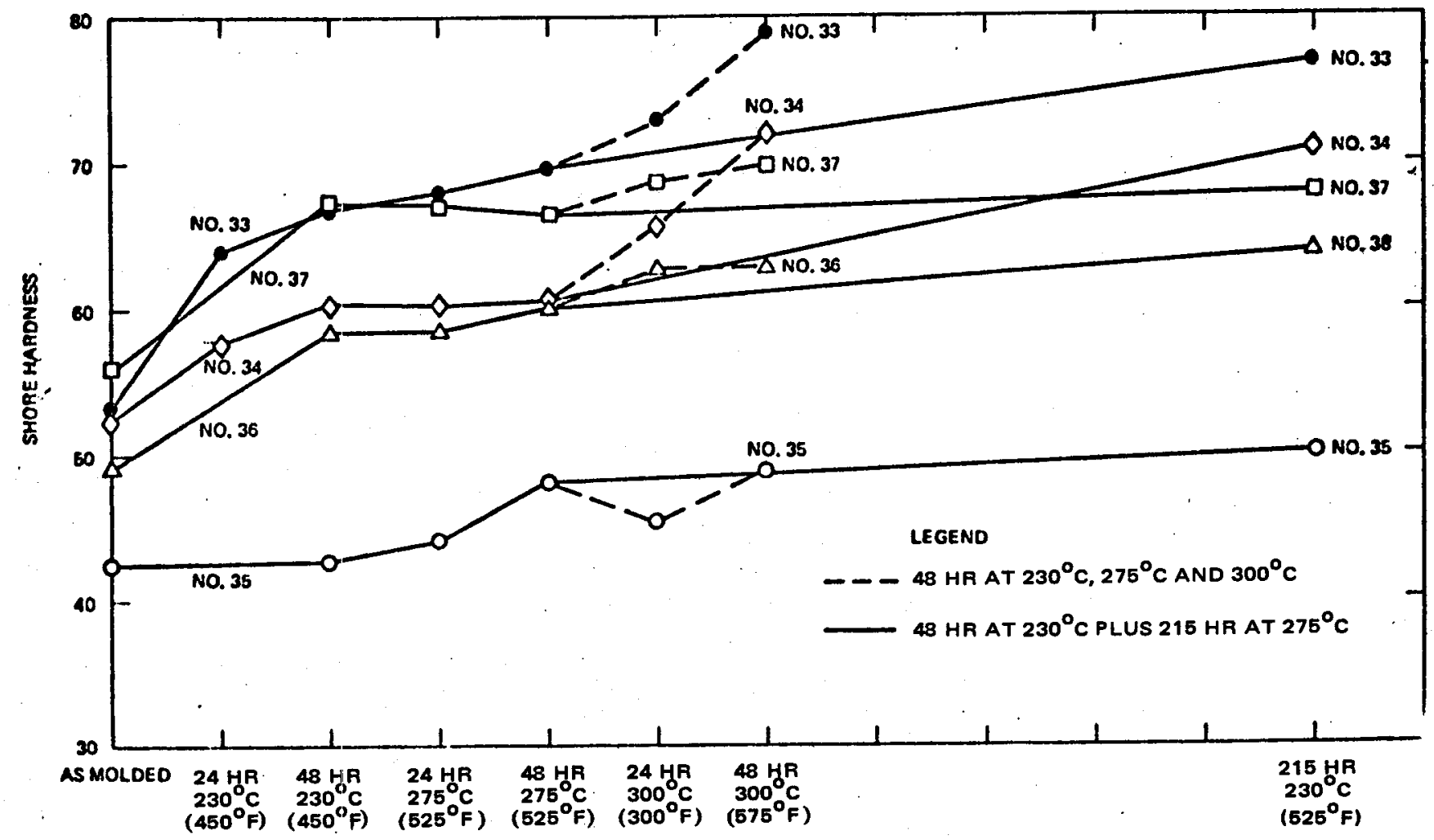

Figure 6. Hardness changes in carborane-siloxane buttons during postcure.

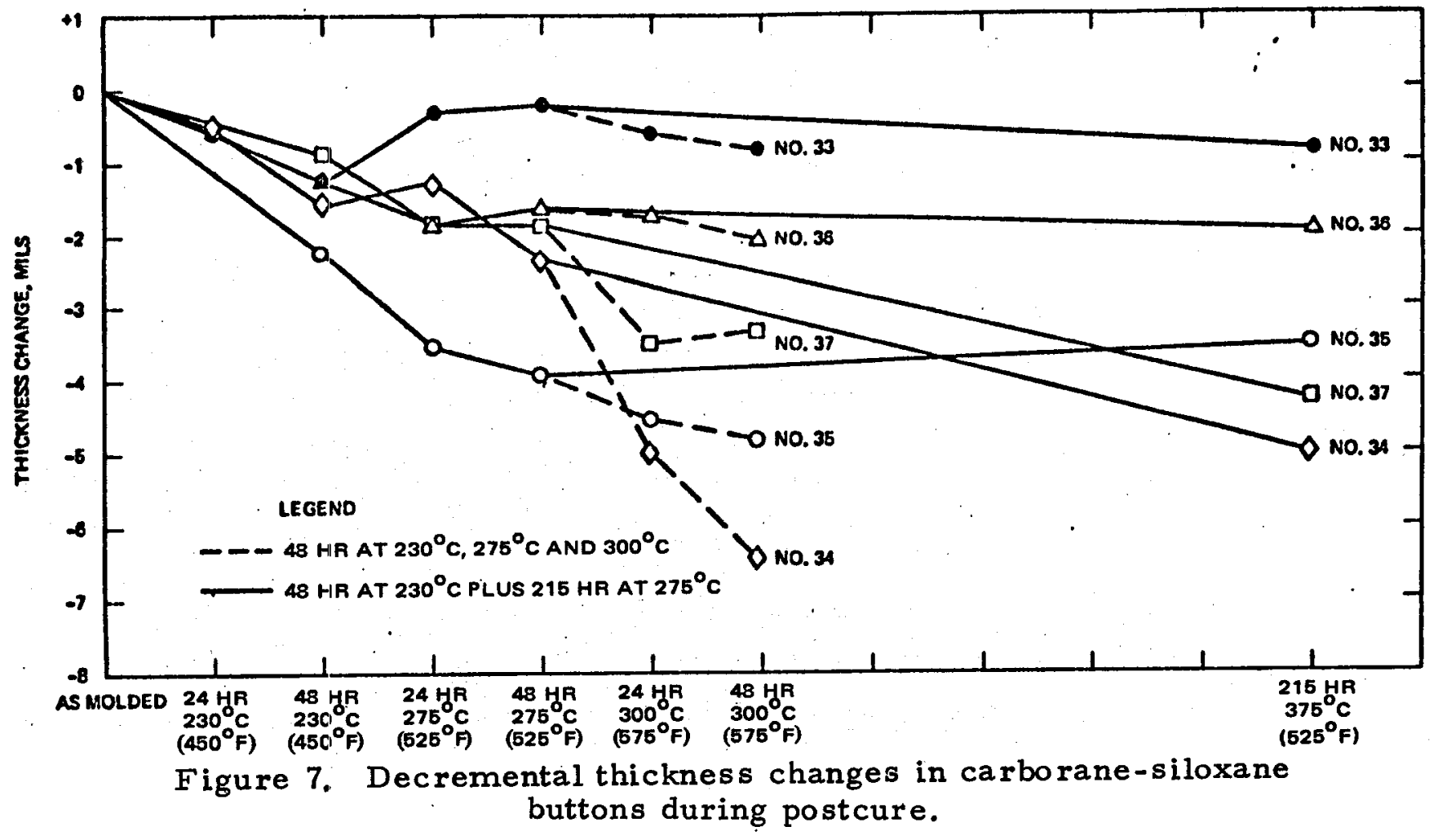


Since the buttons were quite small and somewhat soft, measurements of thickness and hardness were required which were not dependent on operator "feel". To this end, thickness determinations were made using a Randal and Stickney stand mounted dial gage equipped with an $85 \mathrm{gm}$ load. Hardness measurements were made using a Shore A-2 Durometer mounted on a stand, with a total load of $1,258 \mathrm{gm}$. Measurements were taken approximately 1 second after load application.

It should be noted that the final hardness and shrinkage of the samples postcured 215 hours at $275^{\circ} \mathrm{C}\left(525^{\circ} \mathrm{F}\right)$ were not markedly different from those cured 48 hours at $300^{\circ} \mathrm{C}\left(575^{\circ} \mathrm{F}\right)$. It should also be noted that there appeared to be a fair correlation between the amount of shrinkage and the hardness change; i.e., the greater hardness changes also showed the higher shrinkages. This would be expected if the changes were due to crosslinking.

With the development of what appeared to be promising formulations from the standpoint of mechanical properties, it was decided that tests should be made to determine the hydrolytic stability of the formulated compounds.

\section{HYDROLYTIC STABILITY TESTS}

A simple hydrolytic stability test was devised which could be used to determine the effect of high temperatures and high steam pressures on the various polymers. The objectives of the test were three-fold:

1. To determine if the relatively simple apparatus was truly effective in causing deterioration of a number of different polymers and/or if resistant polymers could be found;

2. To establish a convenient hydrolysis test, e.g., 24 hours at $275^{\circ} \mathrm{C}$ in saturated steam;

3. Most important, to establish the resistance of some selected, supposedly resistant, polymers to the hydrolysis test, so they could be used as standards against which the new synthesized materials could be compared.

The apparatus which was used to perform the hydrolytic: stability tests consisted initially of a small iron pressure bottle containing approximately $100 \mathrm{ml}$ of water (Figure 8). After the first tests established the validity of the concept, the sample bottle was succeeded by a somewhat more elaborate 
pressure vessel (shown in Figure 9). Initially, the samples were held in nickel wire cages (shown in Figure 8); in later tests the samples were enclosed in sealed glass ampoules containing a small amount of water (Figure 10) to isolate the samples from the water contained in the pressure vessel. Also, water from the ampoule could then be analyzed without danger of contamination from the walls of the pressure vessel.

Both pressure vessels were simply immersed in a molten Wood's metal bath held at $275^{\circ} \mathrm{C}\left(525^{\circ} \mathrm{F}\right.$ ) (or slightly higher to compensate for radiation and convection losses). The temperature inside the containe $r$ was determined by noting the pressure and by use of standard steam tables. The apparatus worked very satisfactorily, and because of its low cost and simplicity, is being considered for adoption by the ASTM as a method of preliminary screening of geothermal seal materials.

The first tests were made with the best of the carborane-siloxane formulations. The samples, both in the wire cages and in the ampoules, showed complete disintegration within 24 hours. Analysis of the deionized water used as the hydrolytic medium, when the button was contained in a sealed glass ampoule (as shown in Figure 10), showed 40 ppm of boron. (Normal tap water in Culver City has approximately $5 \mathrm{ppm}$.) It was thus concluded that the boron cage was being broken. Further tests, using commercially available 50 Shore A silicone rubber showed the same type of deterioration. It was thus concluded that both the carborane moiety and the siloxane moiety were extremely vulnerable to hydrolytic deterioration at the temperature and pressures used. The disintegration of the carborane was confirmed by a thermodynamic calculation of the reaction

$$
1,7-\mathrm{C}_{2} \mathrm{~B}_{10} \mathrm{H}_{12}+34 \mathrm{H}_{2} \mathrm{O} \longrightarrow-10 \mathrm{H}_{3} \mathrm{BO}_{3}+2 \mathrm{HCOOH}+23 \mathrm{H}_{2} \uparrow
$$

The standard enthalpy at ambient temperature, $\Delta \mathrm{H}_{f}^{\circ}$, for this reaction is about $-348 \mathrm{Kcal}$. Because of enthalpy conside rations, the standard free energy, $\Delta G_{f}^{0}$, for this reaction would be negative and therefore the reaction would be spontaneous as written. The calculations, of course, do not indicate the rate at which the reaction would take place. However, the hydrolysis test showed that the rate was appreciable at the temperature 

I:
.

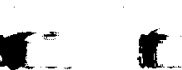
$r c$
$r: r r$
$r$
$r$
$t r+c t r c$

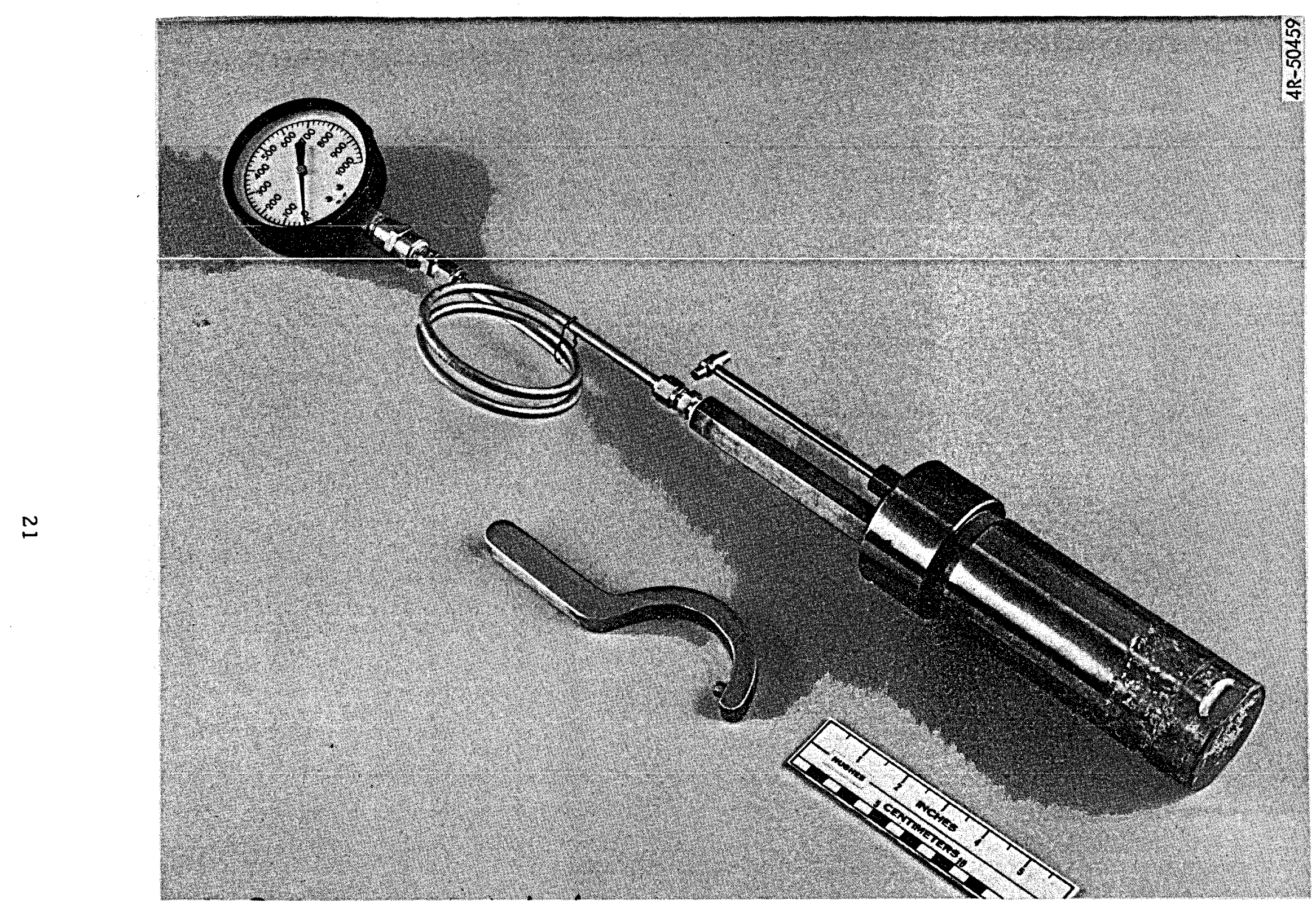

Figure 9. Improved hydrolysis equipment. 


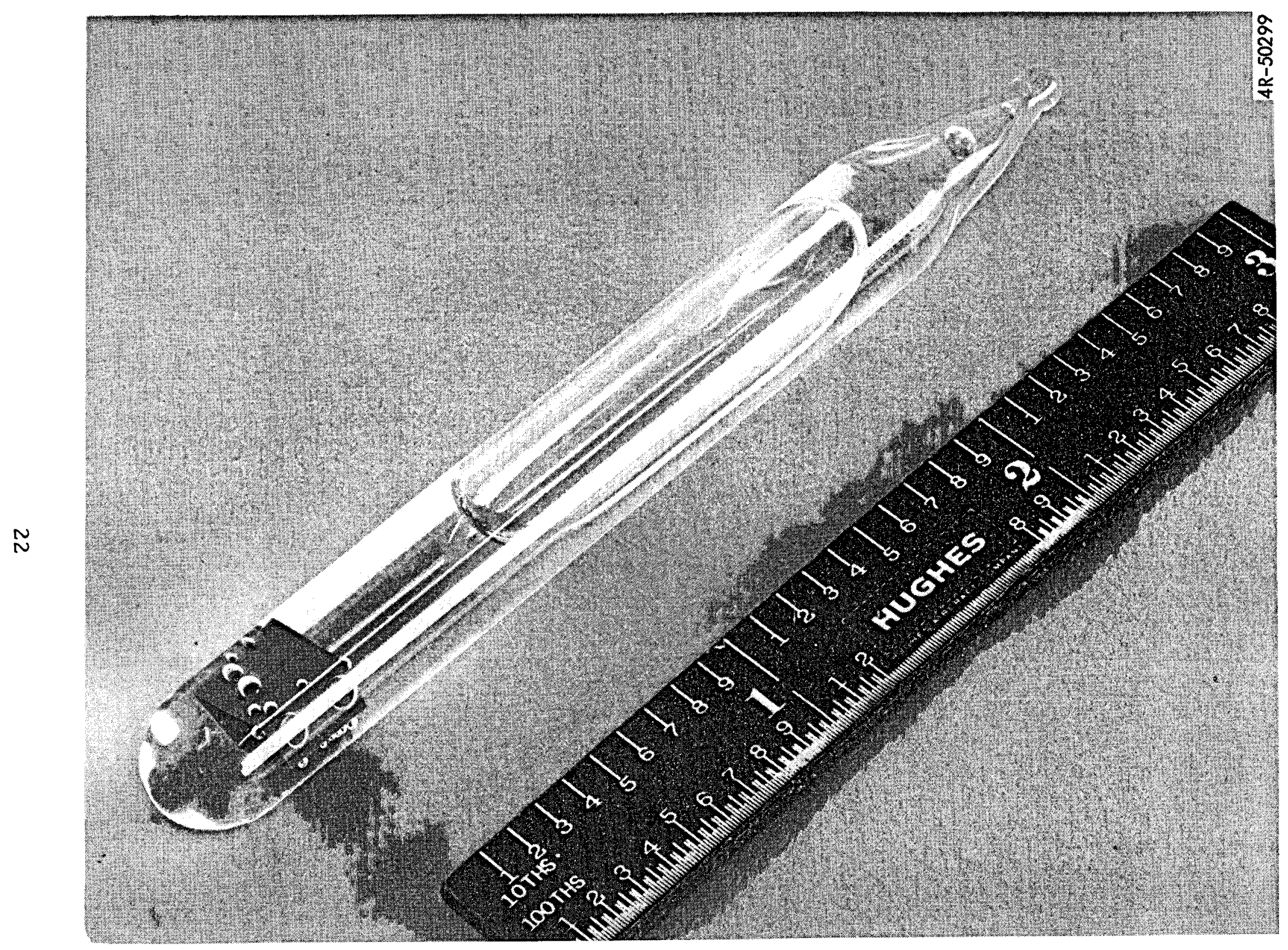

Figure 10. Hydrolysis test sample ampoule.

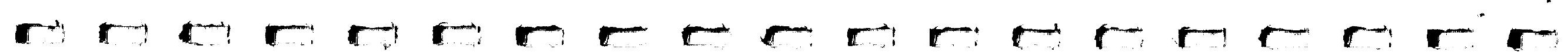


used. The decomposition was also accelerated by the relatively high pressures involved. Based on these findings, work was discontinued on the carborane-siloxane polymers.

Additional tests were also made on small pieces of commercially available 50 Shore $A$ silicone rubber. This material also completely depolymerized in 16 to 24 hours in a manner similar to the carboranesiloxane. A search was made in the literature to see if this phenomenon was reported. A personal inquiry to a source at Dow Corning Company confirmed that high temperature, high pressure steam was used routinely for depolymerization of silicone polymers.

A numb er of other tests were run on various polymers - some synthesized at Hughes and some procured from outside sources. The results of these tests are shown in Table IV.

These results indicate that only those polymers which had C-C bonds as the polymeric backbone were unaffected by the the water (Teflon, for example). Although:some materials such as polyphenylene oxide would be expected to hydrolyze into phenolic compounds, the rate was slow enough to justify their consideration as candidate structures. These considerations were used as guidelines for the selection of candidate synthesis materials. Ideally they should be completely non-reactive with water, but consideration was given to materials which could be expected to react slowly enough with water to give useful "in-use" life.

\section{FLUOROALKYLENE SILOXANE ELASTOMER}

A fluoroalkylene siloxane polymer (an analogue of "Fasil"), based on work done at Wright-patterson Air Force Base, was also synthesized for test. This material, although not described in the original proposal, was considered theoretically promising and work was initiated pending receipt of intermediates for the perflouroalkylene oxide elastomer synthesis. The synthesis of the flourinated siloxane was carried out first by preparation of three intermediates - a diol, 1,3-bis (hydroxydimethylsilyl)benzene, and 
TABLE IV. HYDROLYTIC STABILITY TESTS

\begin{tabular}{|c|c|c|c|c|c|c|c|}
\hline \multirow[b]{2}{*}{$\begin{array}{l}\text { Test } \\
\text { No. }\end{array}$} & \multirow[b]{2}{*}{ Material } & \multirow[b]{2}{*}{ Visua1 Results } & \multicolumn{4}{|c|}{ Chemical Analysis } & \multirow[b]{2}{*}{ Remarks } \\
\hline & & & $\begin{array}{c}\text { Gas } \\
\text { Evol. }\end{array}$ & $\mathrm{pH}$ & $\mathrm{F}^{-}$Ion & $\mid \begin{array}{c}\mathrm{CC}_{4} \text { Extract } \\
\text { of } \mathrm{H}_{2} \mathrm{O}\end{array}$ & \\
\hline 1 & Carborane-siloxane rubber & Complete deterioration & Yes & -- & -- & & \\
\hline 2 & $\begin{array}{l}\text { HAC amide fluoroelastomer } \\
\text { (solid) }\end{array}$ & Bad disintegration & Yes & -- & -- & & \\
\hline 3 & $\begin{array}{l}\text { Krytox } 143-\mathrm{AC} \text { perfluo roalkyl } \\
\text { polyether lubricating oil } \\
\text { mol wt } \approx 5000\end{array}$ & Very little or no effect seen & No & 6 & Neg & Neg & $\begin{array}{l}\text { IR of oil on bottom matches } \\
\text { original IR. Non-volatile } \\
\text { residue negative }\end{array}$ \\
\hline 4 & OS-124 (pentaphenylene oxide) & $\begin{array}{l}\text { A ppeared significantly affected, } \\
\text { water very cloudy }\end{array}$ & No & 6.8 & -- & Neg & $\begin{array}{l}\text { Phenol spot test negative } \\
\text { no phenol odor }\end{array}$ \\
\hline 5 & $\begin{array}{l}\text { Braycote } 816 \mathrm{Z} \text { perfluoroalkyl } \\
\text { polyether copolymer lubri- } \\
\text { cating oil mol wt } \approx 13000\end{array}$ & $\begin{array}{l}\text { Slight cloudiness in solution, } \\
\text { breakdown? }\end{array}$ & No & 6 & Positive & $\mathrm{Neg}$ & $\begin{array}{l}\text { Oil characteristic. Non- } \\
\text { volatile residue negative }\end{array}$ \\
\hline 6 & Teflon TFE & No discernible effect & No & 6 & -- & -- & Cleałr colorles \\
\hline 7 & Diphenyl ether & $\begin{array}{l}\text { Large amount of cloudiness } \\
\text { emuls ification? }\end{array}$ & - & -- & -- & -- & -- \\
\hline 8 & Polyphenylene oxide pellets & $\begin{array}{l}\text { Pellets melted together, but } \\
\text { showed no evidence of depoly- } \\
\text { merization. }\end{array}$ & -- & -- & -- & -- & Slight odor of phenol. \\
\hline 9 & $\begin{array}{l}\text { HAC ketone fluoroelastomer } \\
\text { unpurified, Ag containing } \\
\text { powder } *\end{array}$ & Significant deterioration & Yes & 10 & Positive & $\mathrm{Neg}$ & $\begin{array}{l}\text { Ag found. Nonvolatile resi- } \\
\text { due contained degradation } \\
\text { products }\end{array}$ \\
\hline 10 & $\begin{array}{l}\text { HAC ketone fluoroelastomer } * * \\
\text { (purified) }\end{array}$ & $\begin{array}{l}\text { Material appeared substan- } \\
\text { tially unchanged, some } \\
\text { deterioration }\end{array}$ & No & 4.5 & Positive & $\begin{array}{l}\text { Siloxane } \\
\mathrm{CH}_{3}\end{array}$ & Slight odor in water. \\
\hline 11 & Silicone rubber - 50 Shore* & Complete depolymerization & -- & -- & -- & - & \\
\hline 12 & 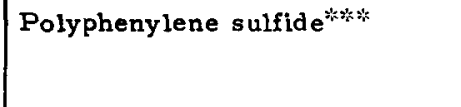 & $\begin{array}{l}\text { No apparent effect except lighter } \\
\text { color }\end{array}$ & Yes & 6.8 & -- & Neg & $\begin{array}{l}\text { Slight swelling } \approx 16 \% \text {. } \\
\text { No IR change. Sulfur } \\
\text { odor }\end{array}$ \\
\hline 13 & Kalrez ${ }^{2 * 2 *}$ & No apparent effect & $\begin{array}{l}\text { Yes } \\
\text { (High) }\end{array}$ & $<1$ & $\begin{array}{l}\text { Strong } \\
\text { Positlve }\end{array}$ & Neg & $\begin{array}{l}\text { No IR effect. } \mathrm{SiO}_{2} \\
\text { residue. } \approx 5 \% \text { swell }\end{array}$ \\
\hline \multicolumn{8}{|c|}{$\begin{array}{l}\text { * These tests run at } 235^{\circ} \mathrm{C}\left(450^{\circ} \mathrm{F}\right) \text { and } 400 \mathrm{psi} \\
* \text { Run for } 45 \text { hours at } 235^{\circ} \mathrm{C}\end{array}$} \\
\hline
\end{tabular}


two substituted diamino silanes. These intermediates were prepared as shown below:
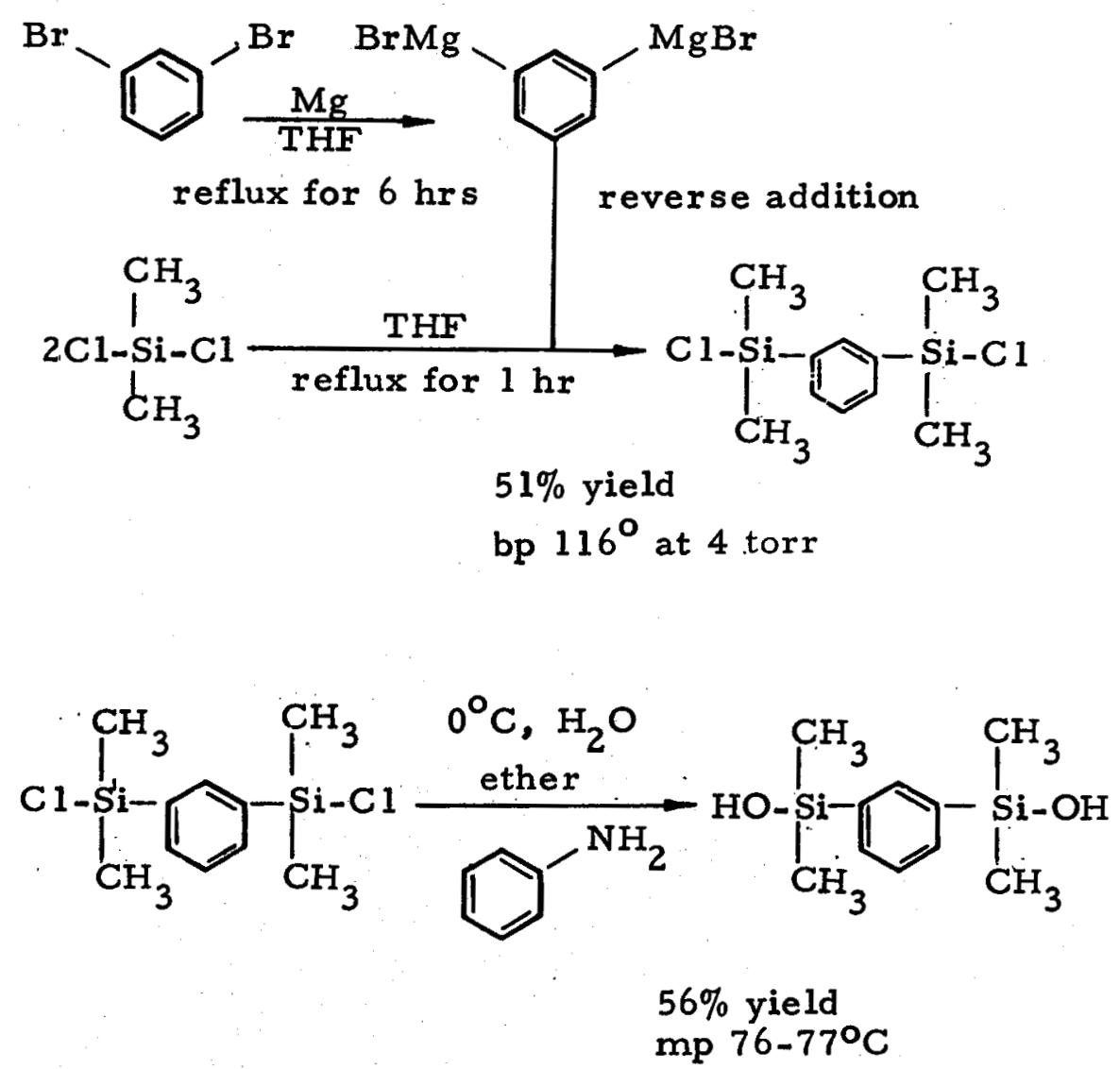

The Grignard reagent formed from m-dibromobenzene was added to dichlorodimethylsilane to give 1,3-bis(chlorodimethylsilyl)benzene, which was subsequently hydrolyzed to the diol (I), as shown above.

The second intermediate, bis(diethylamino)methyl(3, 3, 3-trifluoropropyl)silane, was made as shown below:

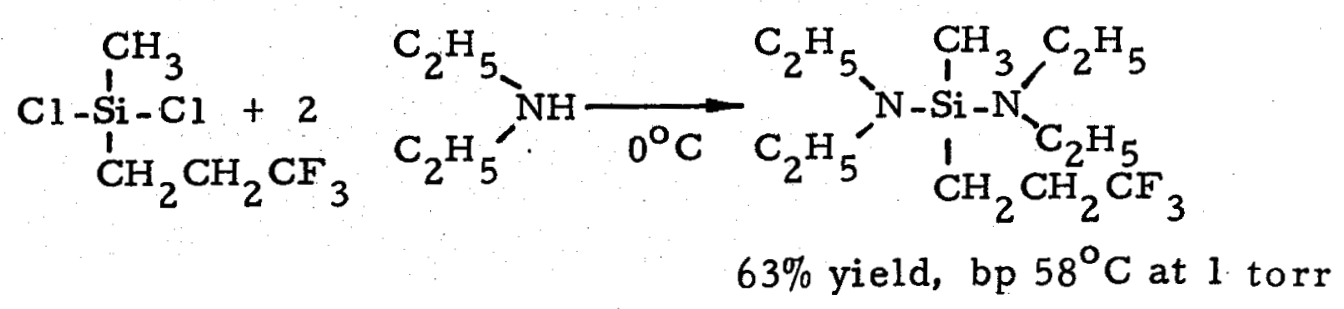


The third intermediate, bis(diethylamino)methylvinylsilane, which incorporated a vinyl group in the molecule to act as a crosslinking agent, was prepared as shown below:

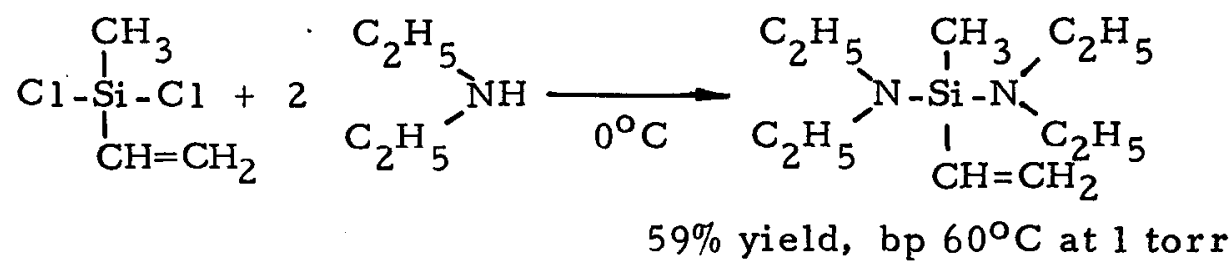

A subsequent polymerization reaction with compounds I, II, and III in the ratio 50:49:1 was carried out in 1,2-dichloroethane. The resulting polymer had the following structure:

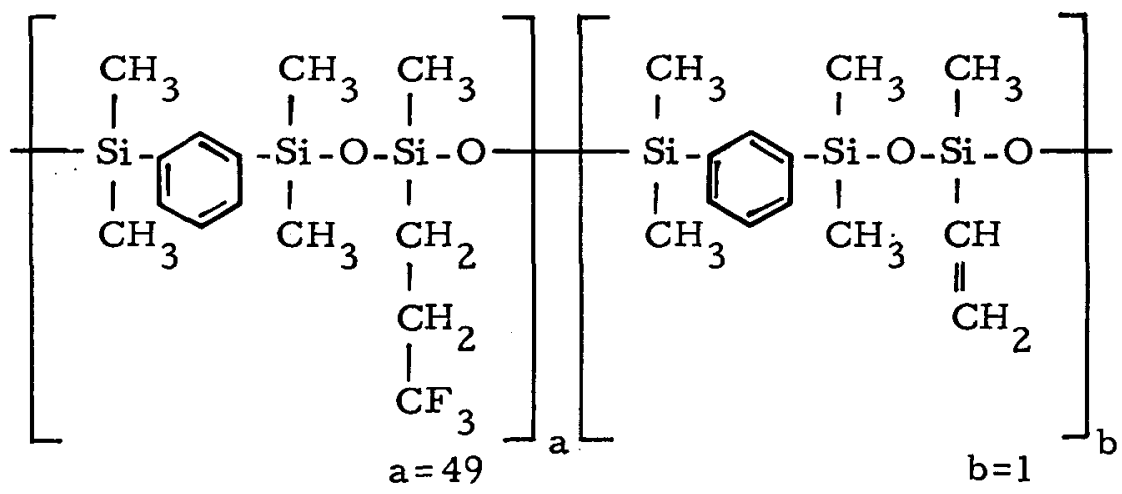

The reaction proceeded with the elimination of diethylamine. The product was crosslinked with benzoyl peroxide as an activating agent, which resulted in a gummy material. The consistency of the gum was such that it was felt that more crosslinking was needed. In a second $r$ un, the solvent for the polymerization reaction was changed from 1,2-dichloroethane to tetrahydrofuran. The compounds I, II and III were reacted in a 50:48:2 ratio, thus doubling the number of crosslinking sites, which resulted in a stiffer gum stock after cure.

The polymer IV was synthesized from $8.91 \mathrm{~g}$. of bis(hydroxydimethylsilyl)benzene, $0.51 \mathrm{~g}$ of bis(diethylamino)methylvinylsilane, and $10.76 \mathrm{~g}$ of bis(diethylamino)methyl(3,3,3-trifluoropropyl)silane, with evolution 
of diethylamine. The reaction was continued for a week with increased heating by oil bath and applying of vacuum to remove the gaseous amine. The polymer formed was viscous, brown and weighed $11.54 \mathrm{~g}$. Further work on this polymer was stopped when it was discovered that siloxane type polymers did not withstard high temperature hydrolysis tests.

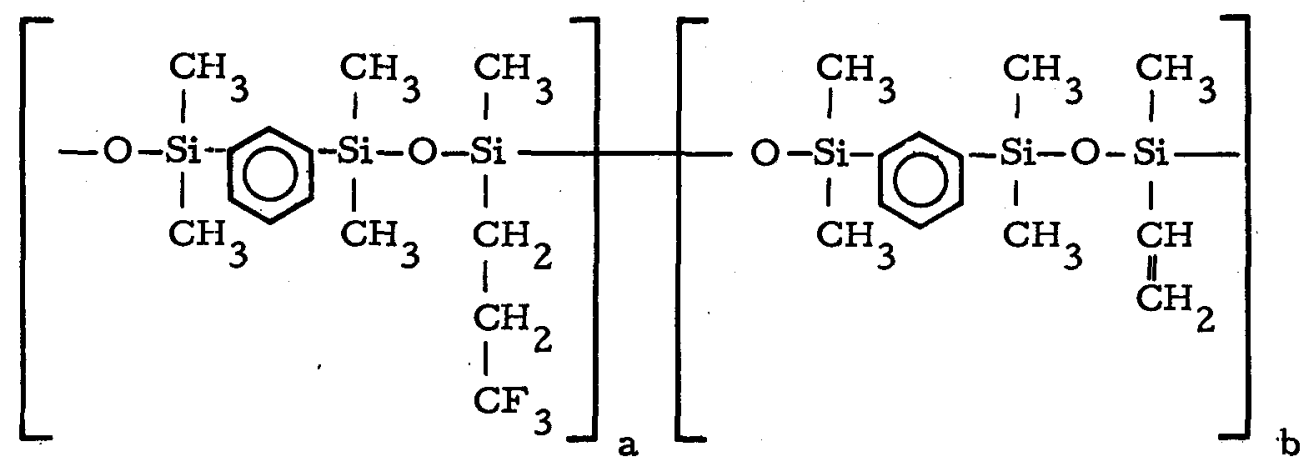

$a=48 ; b=2$

\section{E. PERTLUOROALKYLENE OXIDE ELASTOMER}

\section{Precursor Polymerization}

The original synthesis route for the production of the proposed perfluoroalkylene oxide elastomer was based on the use of an acyl halide terminated perfluoroalkylene oxide procured from PCR Research Chemicals, Inc., Gainesville, Florida. The structural formula of the PCR material is shown below:

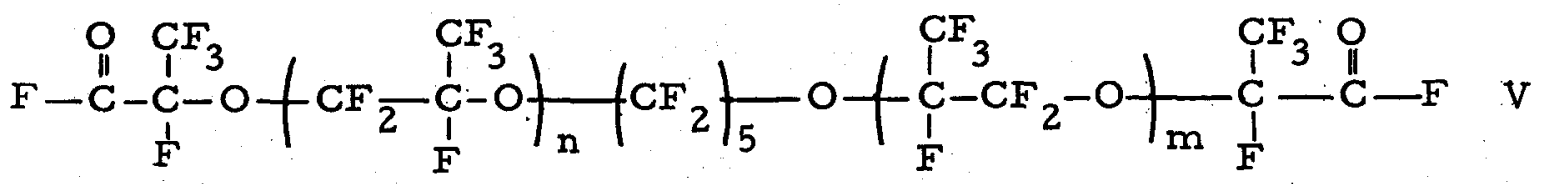
where $n+m=6,7$ or 8

Because it was perfluorinated it was felt that the compound should have outstanding elevated temperature and hydrolysis resistance. Furthermore with the initially high molecular weight, polymerization through the terminal function groups would introduce a minimum of crosslinks and should result in an elastomeric polymer. There was very little information at the 
beginning of the program regarding the reactivity of this compound and there was no significant literature describing polymers obtained from V. (In late 1977 there appeared one report on the preparation of block copolymers based on V linked with 1,2,4-oxadiazole units. 1 Although this compound<smiles>[R2]c1noc(C(C)(C)C)n1</smiles>

is reported to have elastomeric properties, there is some question as to whether the oxadiazole ring would have significant hydrolytic stability since water is eliminated during its formation.)

Additionally the re is almost no information in the chemical literature regarding hydrolytic stability of organic compounds at $275^{\circ} \mathrm{C}$ and 830 psi steam. The relevance of information regarding thermally stable polymers is questionable as shown by other parts of this program. Therefore, in designing the linking groups for the proposed elastomer based on $V$, several assumptions were necessarily made regarding the hydrolytic stability of different chemical units. Groups which have been shown to be thermally unstable such as methylene linkages were assumed to be no better in an aqueous environment at these elevated temperatures. Groups which are hydrolyzible under mild hydrolysis, such as

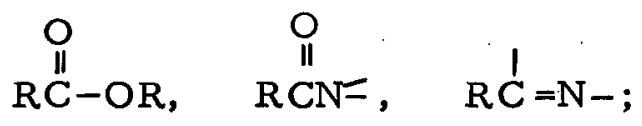

were also considered unsuitable. Other functionalities which are thermally stable but which have a hydrolytic stability that is not sufficiently well defined, include

\footnotetext{
${ }^{1}$ NASA patent disclosure, Case No. ARC-11060-1 dated 17 October 1977.
} 
<smiles>[R][Si]([R])(CC)OC(C)CC</smiles>

The final category of functional groups included those that had proven thermal stability and likely hydrolytic stability, such as

$$
-\left[\mathrm{CF}_{2}-\mathrm{O}-\mathrm{CF}_{2}\right]-, \quad \stackrel{\mathrm{I}}{\mathrm{R}} \mathrm{CR},-0 \mathrm{O}-\mathrm{O}-0
$$

The net effect of these restrictions was to limit the available linking groups to these few.

In addition to the requirement of hydrolytic stability, the polymer had to be elastomeric. It is a matter of experience that all substances exhibiting a high degree of rubber-like elasticity contain long chain structure and very few crosslinks. The polymer must decrease in entropy on stretching and the re must be sufficient freedom of molecular motion to allow this distortion to take place rapidly. It follows from this fact that the polymer must be used above its $\mathrm{Tg}$, must be amorphous, and the minimum molecular weight between crosslinks should be at least 50,000 .

Using the above as a guideline, it was initially intended that the perfluorinated alkylene oxide would be polymerizable into a long chain polymer by means of acetylene terminations. The selection of acetylene functional groups as the chain extenders was made because of the long and successful experience at Hughes Aircraft Company in the use of acetylene terminations in polymer formation.

\section{a. Benzene Condensation Reactions}

The first attempt involved a condensation reaction with benzene, followed by acetylation of the phenyl and subsequent conversion of the acetyl 
groups into ethynyl groups via a Vilsmeyer reaction. This would result in sites for curing and chain extension. The proposed reactions are shown below:<smiles>[R]C(=O)C(=O)F</smiles><smiles>[R2]C(=O)c1cccc(C(C)=O)c1</smiles>

Oligomer VI could polymerize by trimerization to produce structures of the type shown below.

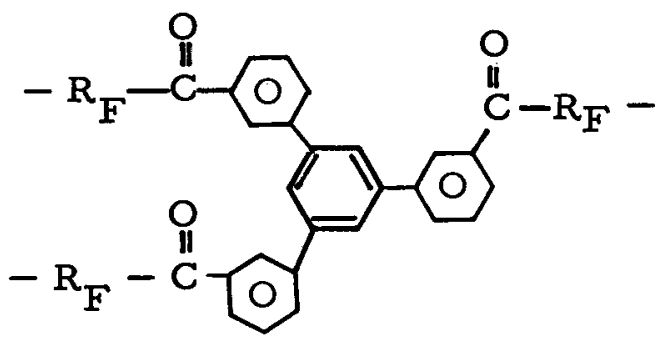

VIA

This polymer would have a 2000 molecular weight moiety between crosslinks if all of the terminal groups were acetylene, or higher molecular weight if a fraction was phenyl terminated. This material was never obtained in the pure state for meaningful evaluation. An excess of benzene was mixed with the perfluorinated compound, and $\mathrm{BF}_{3}$ was used as the catalyst in a Friedel-Crafts type reaction. The reaction was run at benzene reflux temperatures, with vigorous stirring, but the desired product was not obtained. The acyl fluoride, with a molecular weight of $\approx 2000$, was too insoluble, so 
a two-phase, heterogeneous mixture resulted which did not allow the reaction. to proceed. $\mathrm{BF}_{3}$ was used instead of the more common $\mathrm{AlCl}_{3}$ Friedel-Craft catalyst, since $\mathrm{BF}_{3}$ is known to have a higher order of reactivity with acyl fluorides than $\mathrm{AlCl}_{3}$. No further work was therefore done on this approach.

\section{b. Ethynylbenzamide Terminations}

Since it was not found feasible to form the acetylene terminations on the perfluorinated compound by the above route, a second attempt was made in which $\mathrm{m}$-aminophenyl acetylene was reacted with the perfluoroalkyleneoxide oligomer to form an acetylene-terminated amide. The amide, VII, was produced as a model compound because its synthesis bypassed the synthetic difficulties encountered in preparation of VI. The acetylene terminations would again be used for chain extension. The reaction is shown below:<smiles>[R2]C(=O)C(=O)F</smiles>

This compound, when heated, polymerized satisfactorily at $250^{\circ} \mathrm{C}$; unfortunately, it yielded a hard, non-fusible polymer, presumably due to excessive crosslinking.

It was theorized that incorporation of a small amount of a non-crosslinkable moiety would inhibit the formation of the rigid polymer and would result in formation of an elastomer. Such a compound was made in which a non-acetylenic end group (benzene) was used on one end of the amide prepolymer. A mixture of the acetylene-terminated prepolymer and the non-acetylene-terminated prepolymer was thermally cured at $210^{\circ} \mathrm{C}$ to result in a rubbery end-product. The material, however, showed extensive degradation in the hydrolysis test. This was due, no doubt, to the vulnerability of the amide functional group to attack during hydrolysis. Another attempt, using the same concept, i. e., replacement of some of the functional 
terminals with non-functional groups was made using $\mathrm{N}$-methylaniline in place of part of the aminophenylacetylene. The material was only slightly softer.

\section{c. Ethynylbenzoyl Terminations}

Since the theoretical analysis indicated that a ketone structure should show good hydrolytic stability, a third approach to introduce acetylene termi nations onto the perfluoroalkylene oxide oligomer in a polymerizable compound was to produce an acetylene-terminated perfluoroalkylene ether ketone. It was hoped that this compound would be easier to produce, and would also be capable of being made into a gum stock. The synthesis to form the ketone prepolymer from m-bromophenylacetylene and the bis-acyl fluoride of the perfluoroalkylene oxide is shown below:

$$
\text { - } \mathrm{C}=\mathrm{CH} \frac{1) \text { Lithium diisopropylamide }}{2)\left(\mathrm{CH}_{3}\right)_{3} \mathrm{SiCl}}
$$

BrMg
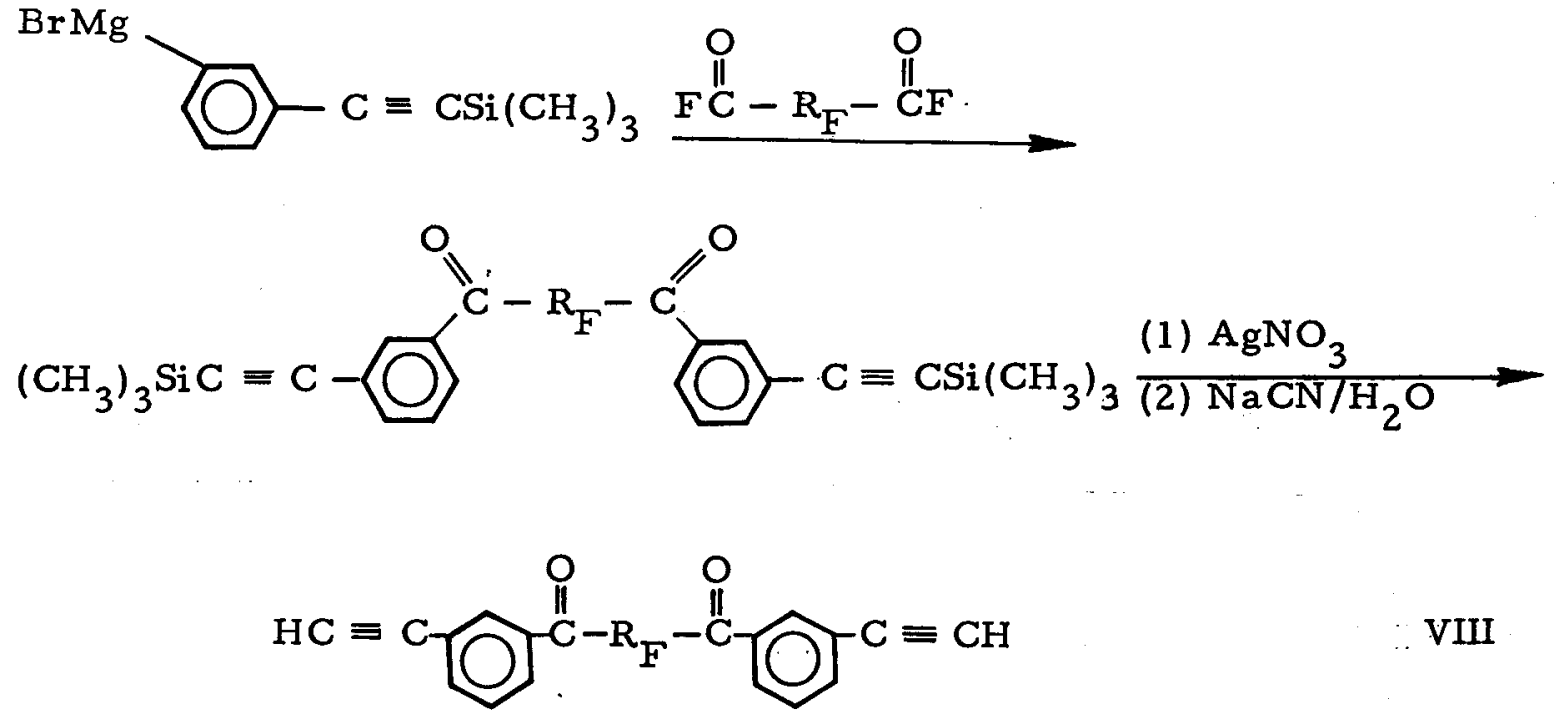
In carrying out this synthesis, problems arose in putting the trimethylsilyl protecting group on the ethynyl group, since the lithium diisopropylamide was of questionable purity. These difficulties were resolved by substitution of butyllithium for the lithium disopropylamide and performing an in-house assay prior to the synthesis so that precise stoichiometry was assured. The final polymer produced after the silver cyanide treatment was VIII. This fluorinated ketone, unpurified, was a gummy material. Hydrolysis tests at $235^{\circ} \mathrm{C}\left(450^{\circ} \mathrm{F}\right)$ and $400 \mathrm{psi}$ pressure indicated significant breakdown in that gas was formed in the ampoule, silver was found in the non-volatile residue, and the $\mathrm{pH}$ of the water was 10 .

After purification, the ketone was again tested for hydrolytic stability. When the ampoule was broken, the contents had a slight odor, and the water, when analyzed, showed the presence of fluoride ions, indicating hydrolysis of the fluorine-carbon bond of the molecule.

\section{Precursor Copolymerization}

\section{a. Phenylene Oxides Copolymerizations}

Another approach to circumvent the experimental problems of synthesizing VI and also to obtain a softer, possibly elastomeric material was to place the acetylene function on an aryl ring separated by several phenylene oxide units from the perfluorinated acyl group. This structure could further be modified by introducing pendent perfluoroalkylene oxide groups (IX) to further flexibilize the cured polymer. This approach

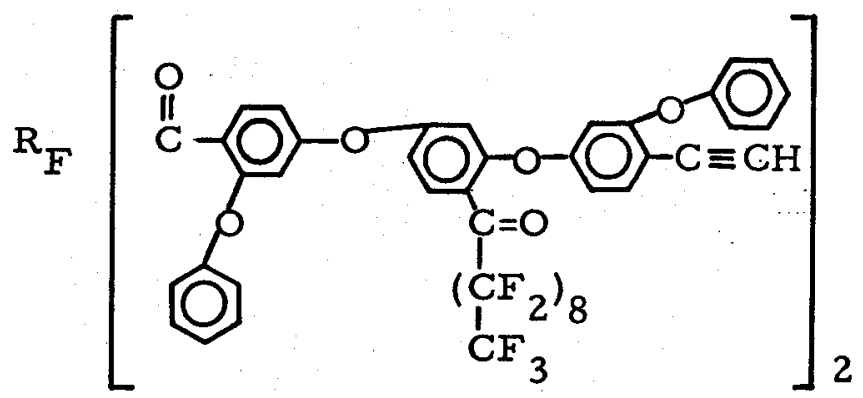


was never completely tested because of problems encountered in purifying the high molecular weight intermediates. Several attempts were made to obtain IX without purification of the intermediates. The tribrominated derivative of pentaphenylene oxide (OS-124, Monsanto Chemical Co.) was obtained by treatment of OS-124 with three equivalents of $\mathrm{Br}_{2}$. This material was monolithiated by treatment with butyllithium and then reacted with the acyl fluoride V. Repeated lithium exchange reactions and reaction with $\mathrm{CF}_{3}\left(\mathrm{CF}_{2}\right)_{8} \mathrm{COF}$ and $\mathrm{CH}_{3} \mathrm{COCl}$ were attempted in order to produce the acetyl derivative of $\mathrm{IX}$, which could be converted to the acetylene. After completion of the several synthetic steps, spectral evidence indicated only a fraction of the crude material was the desired product. This sequence of reactions is shown below.

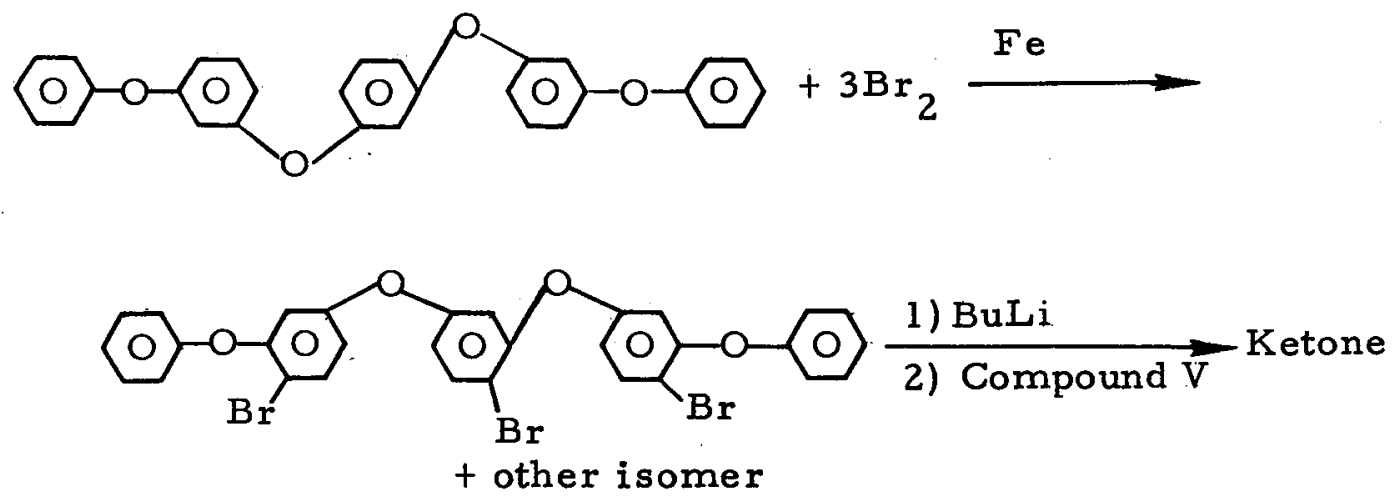

1) $\mathrm{BuLi}$

2) $\mathrm{CF}_{3}\left(\mathrm{CF}_{2}\right) \stackrel{\text { CF }}{\mathrm{C}}$

3) $\mathrm{CH}_{3} \mathrm{COCl}$

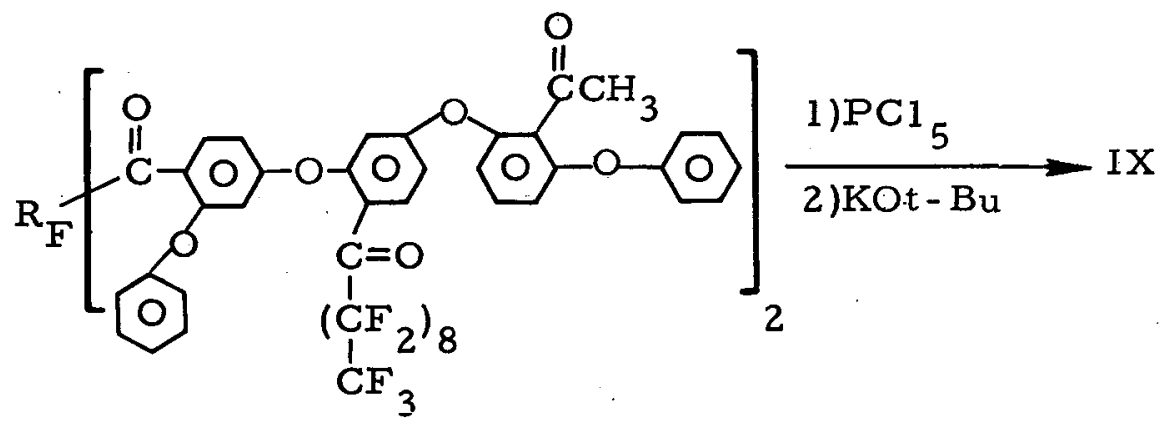


A simplified version of the above reaction was performed with diiodotriphenylene oxide. Grignard reactions were used with more success on the iodo compound as shown below.

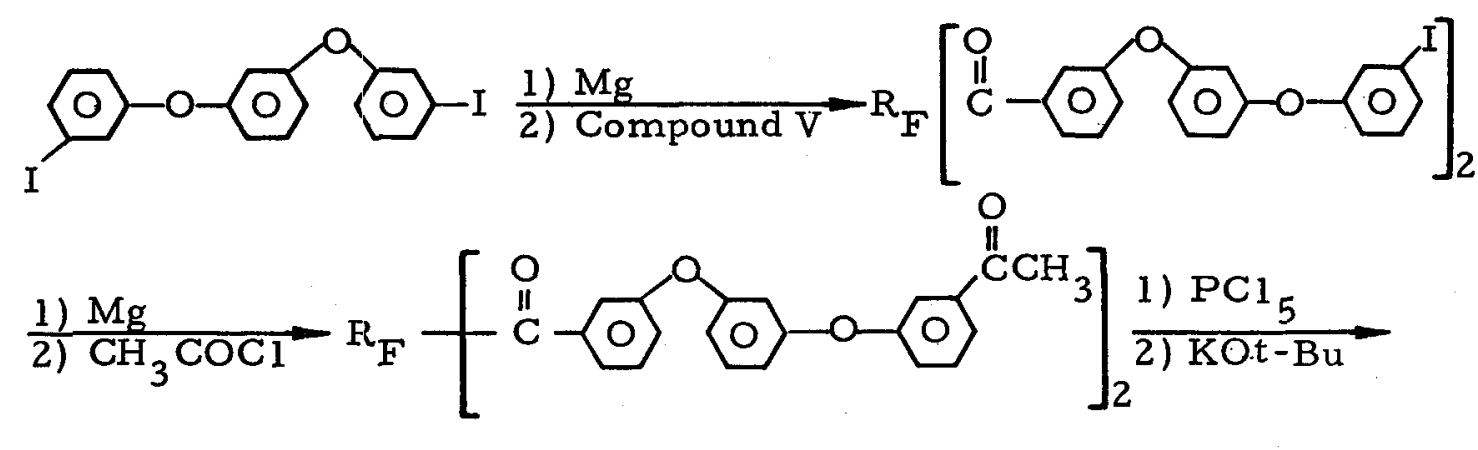<smiles>[R7]CCc1cccc(Oc2cccc(Oc3cccc(C=CC)c3)c2)c1</smiles>

The acetylene-terminated triphenylene oxide was obtained in reasonable purity. A sample was cured thermally to produce a brittle resinous material.

\section{b. Linear Polyphenylene Copolymers}

After it was observed that the first few acetylene-substituted perfluoroalkylene oxide based polymers cured to very hard resins, it was decided to investigate the properties of strictly linear polymers. Since polyphenylene sulfides are useful high temperature thermoplastics, and since they were shown to be hydrolysis-resistant in the initial screening, a simple synthesis for a phenylene sulfide linked material was designed. The previous unsuccessful reactions had provided much information about which reactions on the acyl fluoride, V, were likely to be successful. The bromophenyl terminated derivative was prepared without trouble using the monoGrignard of dibromobenzene. Remarkably, the material of molecular weight 2000 could be purified without decomposition by distillation.

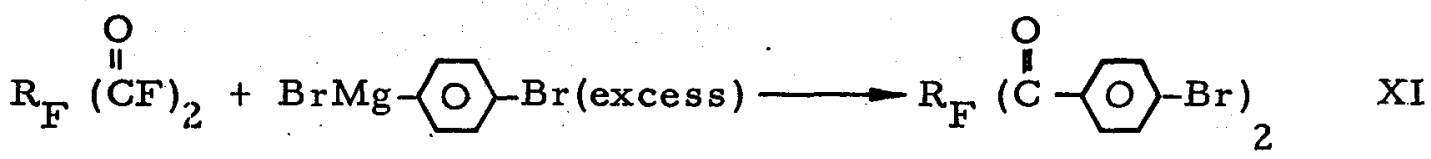


The phenylene sulfide linked polymer was then prepared by reaction of XI with $\mathrm{Na}_{2} \mathrm{~S}$.

$$
\begin{aligned}
& R_{F}(\stackrel{O}{\mathrm{C}}-\mathrm{O}-\mathrm{Br})_{2}+\mathrm{Na}_{2} \mathrm{~S} \stackrel{\text { DMSO or NMP }}{\longrightarrow} \\
& {\left[-R_{F}-\stackrel{O}{\mathrm{C}} 00 \mathrm{O}-0 \stackrel{0}{I I}\right]_{n}}
\end{aligned}
$$

This reaction was performed several times under various conditions. Each time the product was brittle and resinous. This type of product was confirmed by conversations with several Phillips Petroleum personnel (developers of "Ryton," polyphenylene sulfide) who said they had given up on trying to make an elastomeric polyphenylene sulfide. Another possibility was that $\mathrm{Na}_{2} \mathrm{~S}$ was in some unknown way reacting with the ketone function to produce crosslinking.

Subsequently, an attempt was made to obtain a linear triphenylene oxide linked polymer by reaction of XI with disodium resorcinate. Under the strongly basic conditions used in DMSO, the carbonyl function appeared to cleave from the perfluoroalkylene oxide.

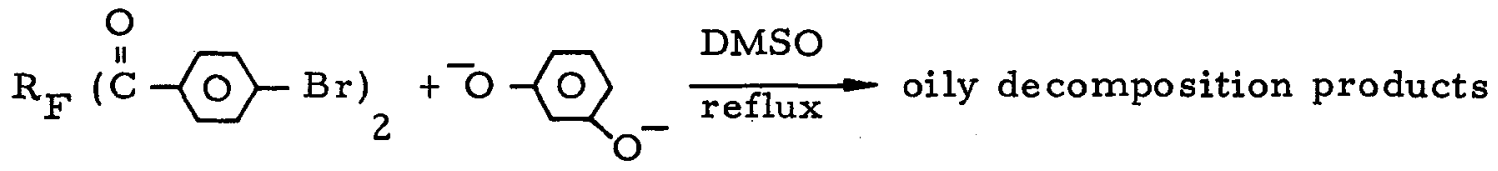

Yet another attempt at making a linear polymer was by Friedel-Crafts reaction with either pentaphenylene oxide or diphenyl ether. It was thought that the failure of the reaction of $\mathrm{V}$ with benzene was due to $\mathrm{BF}_{3}$ not being a strong enough Lewis acid. However, attempts with $\mathrm{SbF}_{5}$ and diphenyl ether or pentaphenylene oxide were also unsuccessful.

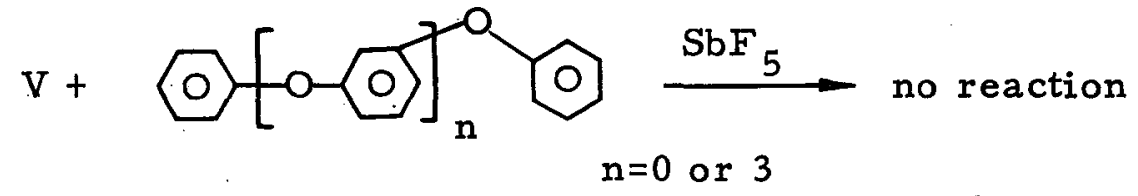


An unsuccessful attempt also was made to produce a biphenyl-linked polymer starting with XI by an Ullman coupling reaction. This was attempted both in pyridine and without solvent. In both cases XI was recovered unreacted.

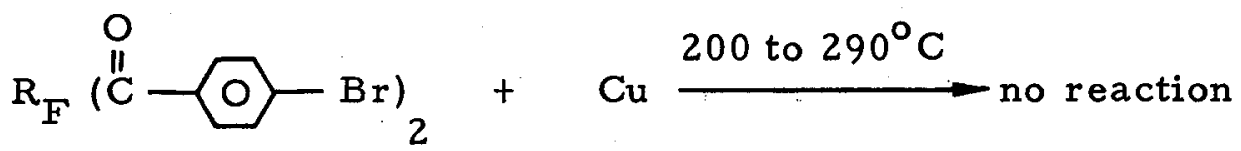

The biphenyl-linked polymer XIII was made directly from the diGrignard reagent of 4, 4'-dibromobiphenyl.

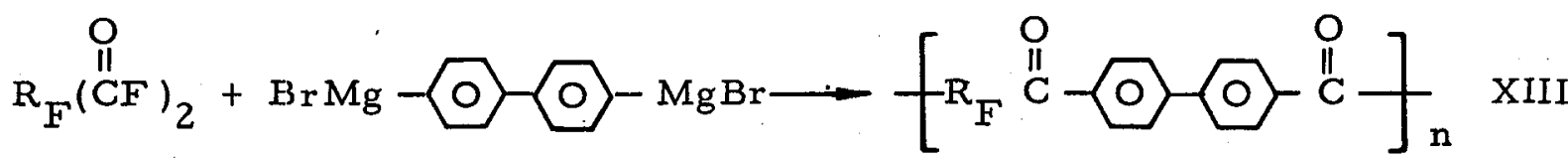

This polymer was hard and brittle after it was completely free of solvent.

c. Discussion

The biphenyl polymer XIII may be thought of as being a linear analog of structure VIA and therefore is as soft as possible for that type of structure. This material unfortunately was the last polymer produced under this program.

The resinous nature of XII and XIII was a completely unexpected result. Since neither polymer has been completely characterized, their structures may be in doubt; i.e., there may exist some crosslinking of an unknown type. Certainly the monomer used in the preparation of XII appears unlikely to yield a resinous polymer. This monomer, XI, was completely characterized by IR (Figure 11), NMR, and elemental analysis, and is a mobile liquid. A side product from the synthesis of XI is the Oligomer XIV, which is a tacky semisolid at room temperature and becomes a slightly viscous<smiles>O=C([R7]C(=O)c1ccc(C(=O)[Z7]C(=O)c2ccc(Br)cc2)cc1)C(=O)c1ccc(Br)cc1</smiles> 


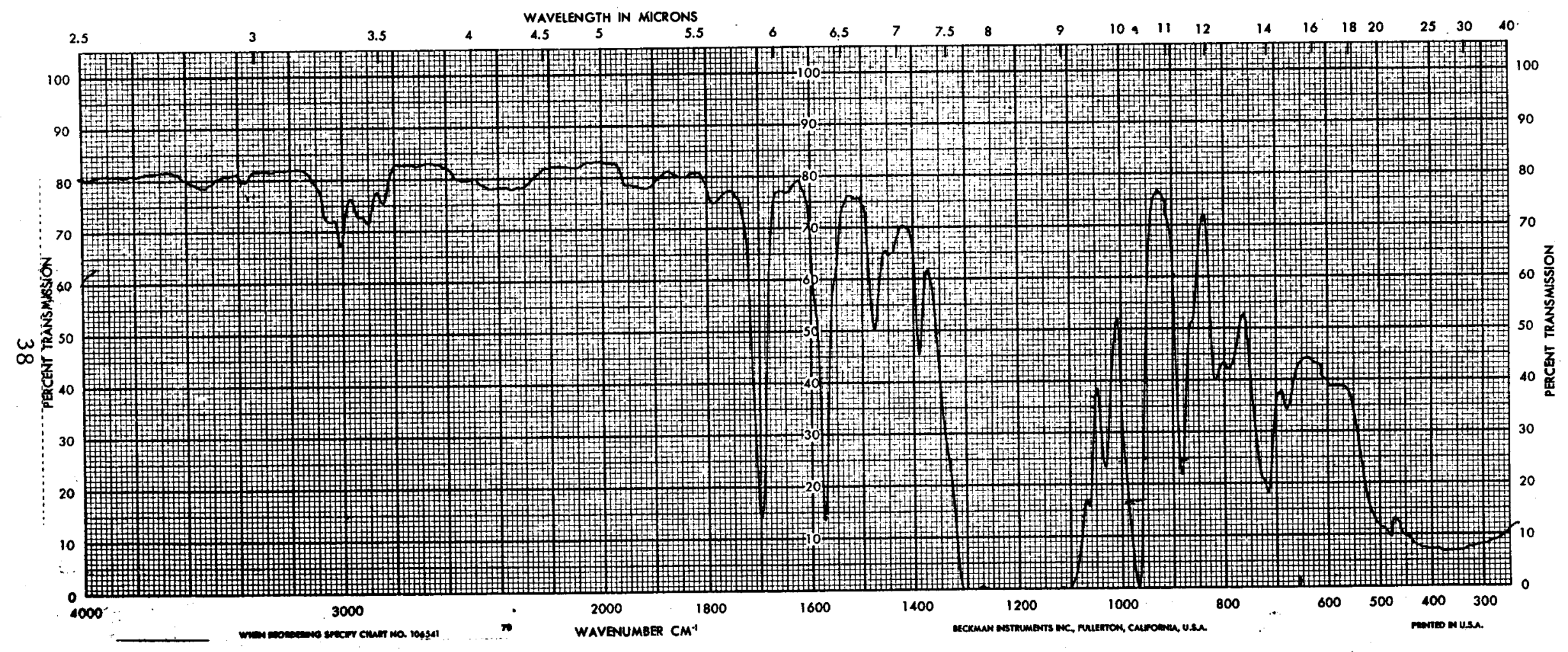

Figure 11. Infrared spectrum of compound XI. 
liquid at elevated temperatures. Its infrared spectrum is shown in Figure 12. It is surprising that by extending the chain from a linear to a presumably linear polymer that the properties changed as drastically as they did.

One possible source of this embrittlement are the ketone groups in the polymer.<smiles>Cc1ccc(C(=O)C(C)C(F)(F)F)cc1</smiles>

The adjacent fluorinated carbon atoms impart unusual reactivity to this carbonyl group. Such compounds as chloral hydrate<smiles>CC(Cl)(Cl)C(O)O</smiles>

exist as stable hydrates because of the electron withdrawing effect of the halogen atoms. In the polyarylene ketone it is possible that there is strong association between adjacent chains through the formation of hemiketals.

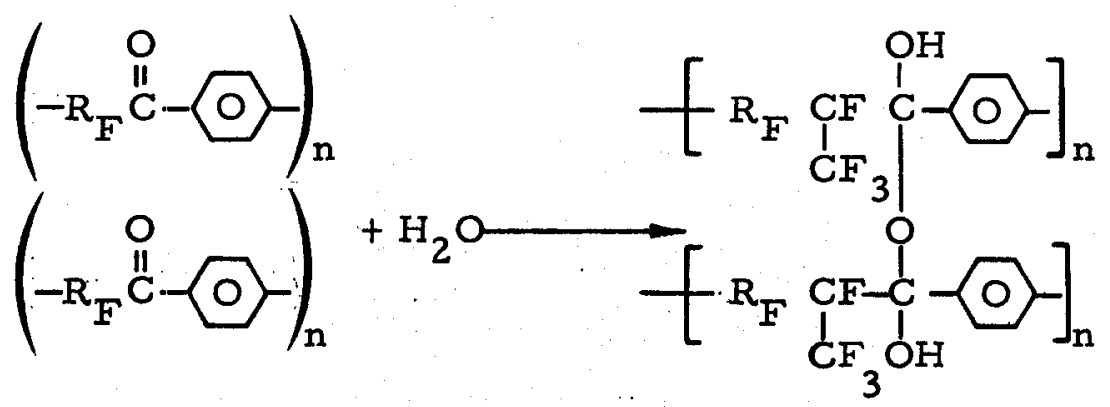

There is no direct evidence to support this mechanism; however, there are many anomolous reactions of $\mathrm{V}$ which are supportive of this reaction. This type of acyl fluoride is reported to form alkoxides by simple treatment with CsF.

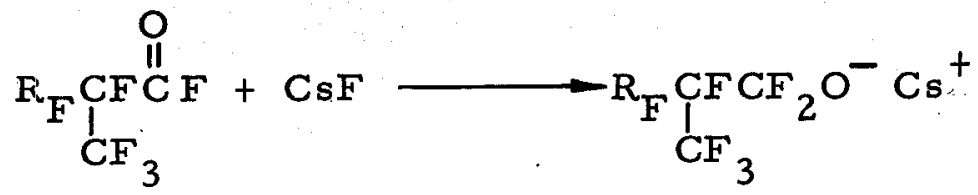




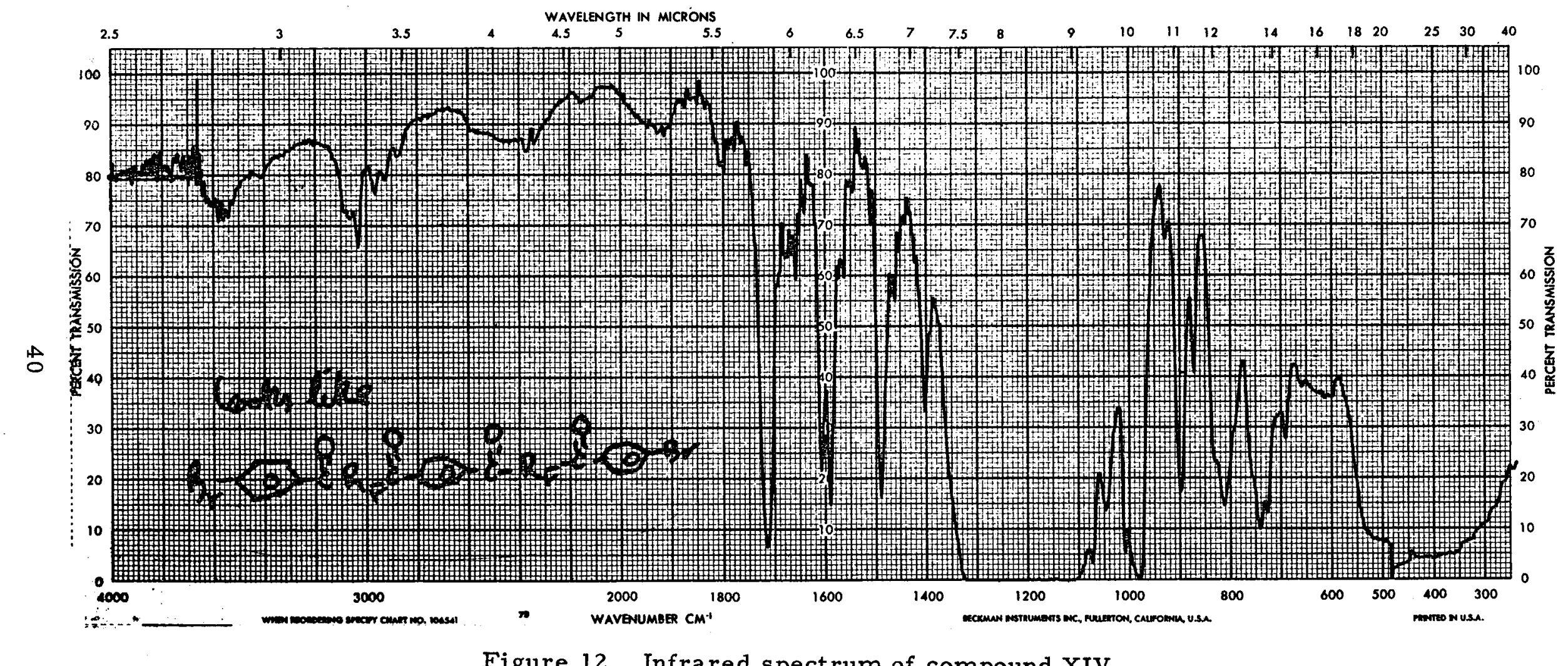

Figure 12. Infrared spectrum of compound XIV. 
This reaction could explain the incomplete formation of the ketone when the acyl fluoride is reacted with lithium aryls in certain solvents. As the ketone is formed, lithium fluoride, which can react with unreacted acyl fluorides, is produced. This is consistent with the observation that magnesium aryls gave better yields of the ketone, possibly because of the lower solubility of $\mathrm{MgF}_{2} \cdot$ Fluoride salts probably react with the ketone as well, helping to prevent reaction with a second equivalent of metal aryl.

There was only one unsuccessful attempt to eliminate this source of

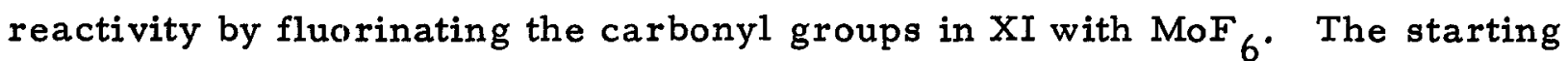
compound was recovered unreacted after this relatively mild treatment. Future work on this potentially promising source of polymers should, as a first step, consider eliminating the carbonyl group.

\section{d. Diphenylbutadiyne Polymerization}

The use of diphenylbutadiyne was investigated. It was considered that the introduction of this moiety as a crosslinking site might result in a more elastomeric polymer than if a simple acetylene termination were used. The theoretical structure of the proposed high polymer is shown below:

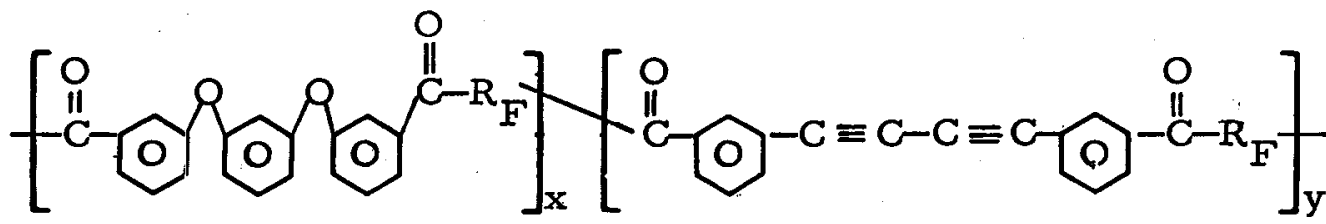

where $R_{F}$ is the perfluoroalkylene oxide structure $V$. The ratio of reactants was chosen so that four or five perfluoroalkylene oxide structures per butadiyne structure were present. The butadiyne moiety can be thermally polymerized and thereby acts as a crosslinking site. The oligomer XV was prepared by reacting a mixture of 1,3-di(3-iodophenoxy)benzene (XVI) and 1,4-di(3iodophenyl)butadiyne (XVII) with butyllithium in hexane to form the lithium derivatives. Diethyl ether and tetrahydrofuran were used as reaction solvents. The lithium derivatives were then reacted with the acyl fluoride $V$. The 
resulting reaction mixture was hydrolyzed and the product extracted with methanol or chloroform. The insoluble portion (about one-half of the total yield) was a powder that can be cured at about $250^{\circ} \mathrm{C}$. The soluble portion was an oil. When tetrahydrofuran was substituted for diethyl ether as the reaction medium, almost all of the product was an oil.

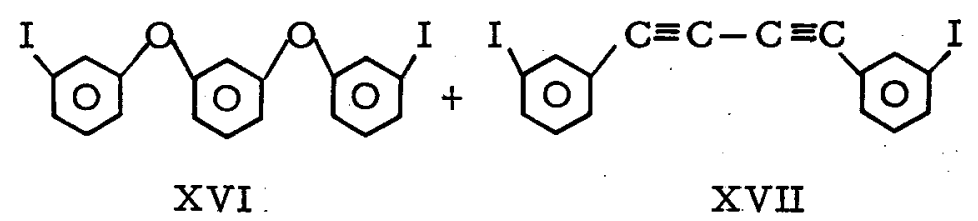

The results of hydrolysis studies on the cured, resinous products are encouraging in that molded and cured resins from these oligomers retained their structural integrity after treatment with steam at $525^{\circ} \mathrm{F}$.

The synthesis of high molecular weight oligomers of the structure shown by $\mathrm{XV}$ is complicated in that the acyl fluoride group can undergo side reactions with the butyllithium. The side reaction which acts as a chain termination step is probably the formation of ketone and then tertiary alcohol as shown below.

$$
\stackrel{\stackrel{O}{C}}{\mathrm{C}}-\mathrm{F} \longrightarrow \stackrel{\stackrel{O}{I}}{\mathrm{C}}-\mathrm{C}_{4} \mathrm{H}_{9} \longrightarrow \stackrel{\stackrel{O}{I}}{\mathrm{C}}\left(\mathrm{C}_{4} \mathrm{H}_{9}\right)_{2}
$$

Also, the possibility of formation of lithium salts such as

$-\stackrel{P}{I}_{F}^{-}-\mathrm{F} \mathrm{Li}^{+}$can possibly take place

Techniques are required to control the kinetics so that the side reactions are minimized and high molecular weight oligomers can be made. However, it is important to note that the oligomer XV would be expected to possess good hydrolytic stability. Further studies on the unique chemistry of the acyl fluoride group could very well lead to a good synthetic approach to the preparation of XV in high enough molecular weight to be useful as a gum stock. 


\section{CONCLUSIONS}

1. The carborane-siloxane gum stock is not satisfactory for fabrication into geothermal seals because of inherently poor hydrolytic stability.

2. It was not possible in the approaches tried to synthesize an elastomeric gum stock using the perfluorinated alkylene oxide as a precursor.

3. Several thermally and hydrolytically resistant non-elastomeric resins where developed as part of this program.

4. A simple, inexpensive hydrolytic stability test was developed which can be used for screening of candidate polymers and elastomeric materials. 



\section{RECOMMENDATIONS}

1. It is recommended that further research be done on methods of causing chain extension of the perfluoroalkylene oxides. Chain extension via the formation of non-hydrolyzable heterocyclic units is likely to be the most fruitful approach. This work must be done prior to, or simultaneously with, work on crosslinking.

2. It is recommended that further investigation be made into the use of the butadiyne moiety as a means of crosslinking oligomers or gum stocks.

3. Further investigation should also be made to exploit the various resinous compounds' developed in this program. In particular, it is recommended that the fluorinated polyphenylene sulfide resin and the fluorinated diphenylbutadiyne resin should be further investigated. 
b 
VI. REFERENCES

(GENERAL BACKGROUND FOR COMPOUNDING)

1. Abrams, E. F. and Shaver, R. G., "High Temperature Elastomer Reinforcing Materials, "AFML Technical Report TR-72-92 Part II, III, IV and V, 1973-1975.

2. Headric, R.G., "Compression Set Investigations for the Fluorocarbon Elastomers," AFML Technical Report TR-65109, Oct. 1965.

3. Pierce, O.R., Riley, M. O. and Lee, K. M., "Elevated Temperature Elastomers for Integral Fuel Tank Sealants, "AFML Technical Report TR-70-278, Part III and VII, 1975-1977.

4. West, A.C., "A New Generation of Fluoroelastomers, "ACS Rubber Div. Meeting, Chicago, Ill., May 1977.

5. Ogintz, S. M., "Perfluoroelastomer O-ring Seals for Severe Chemical and High Temperature Applications," ASLE Meeting, Montreal, Canada, May 1977.

6. Peters, E.N., et al., "D 2 - Meta-Carborane-Siloxanes - Factors Affecting High Performance Properties of Vulcanizates, " Journal of Elastomers and Plastics, 9, 177-185, April 1977.

7. Peters, E. N., et al., "Formulations of Meta-Carborane-Siloxanes," Union Carbide Report CRL-T828, 4 Dec. 1975.

8. Schroeder, H.A., "Carborane-Siloxane Polymers," Rubber Age, Feb. 1969.

9. Schroeder, H. A., "Carborane Polymers," ONR Technical Report No. 50, April 1972.

10. Peters, E. N., et al., "The Preparation and Properties of MetaCarborane--Siloxane Elastomers," ACS, Rubber Div. Meeting, Philadelphia, Penn., Oct. 1974.

11. Ogintz, S. M. and Himmelreich, Jr., "Simulated Se rvice Testing of Jet Engine Seals Using Kalrez O-rings," E. I. DuPont Co. Paper, 9 Dec. 1975.

12. Ogintz, S. M. and Himmelreich, Jr., "The Use of Lucas Stress Relaxation in Compression to Predict Service Life of ECD-006 O-Rings," E.I. DuPont Co. Paper, 16 Dec. 1976. 
13. Kalfayan, S.H., Silver, R.H., and Mzaaeo, A. A., "Accelerated Heat Aging Studies of Fluorosilicone Rubber, " Rubber Chem, and Tech., 48 , (1975).

14. Boonstra, B. B., Cochrane, H., and Dannenbery, E. M. , "Reinforcement of Silicone Rubber by Particulate Silica, "Rubber Chem. and Tech., 48, (1975).

15. Wagner, M.P., "Reinforcing Silicas and Silicates, " Rubber Chem. and Tech., 47, July-Aug. 1973.

16. Foldi, A. P., "Reinforcement of Rubber Through Short Individual Filaments, "Rubber Chem. and Tech., 49, May-June 1976.

17. Polmanteer, K. E. and Lentz, C. W., "Reinforcement Studies - Effect of Silica Structure on Properties and Crosslink Density, " Rubber Chem. and Tech., 48, May-June 1975.

18. Polmanteer, K. E., "New Developments in Silicone Elastomers," J. Elastoplastics, 2, July 1970 .

19. Kojim, G., et al., "A New Fluoroelastomer Derived from Tetrafluoroethylene and Propylene," ACS Rubber Div. Meeting, San Francisco, Oct. 1976.

20. Lewis, F. M. , "The Science and Technology of Silicone Rubber," Rubber Chem. and Tech., 35, Dec. 1962.

21. Sieron, J.K., "Microfiber - Fluoroelastomer Composite Seal Materials, "AFML Tech. Report TR-70-317, Aug. 1971.

22. Williams; J.A., "Carbon Black as a Heat Stabilizer in Silicone Rubber Vulcanizates," U.S. A rmy Report SWEER-TR-72-28.

23. Asti, J., "Perfluoroelastomer for Seals in Natural Energy Production Applications, "Soc. of Petroleum Engineers Paper, SPE 6143, New Orleans, Oct. 1976.

24. Sperling, Leslie M., "Elastomeric and Mechanical Properties of Poly-m-Carbonylene Siloxanes, "Frick Chem. Lab., Princeton, N. J., AD 474092 , Nov. 1965.

25. Gillham, J.K. and Robber, M. B., "Linear Polycarborane Siloxanes," Princeton Univ., Dept. of Chem. Eng., AD-776366, March 1974. 


\section{REFERENCES (SYNTHESIS TECHNIQUES)}

\section{Perfluoroelastomer (Proprietary Section of Previous Reports)}

1. M. Newman, G. Fraetel and W. Kirn, J. Org. Chem., 28, 1851 (1963).

2. H. Staab and K. Neunhoeffer, Synthesis, 424 (1974).

3. R. Benkeser and R. Hicknes, J. Am. Chem. Soc., 80, 5298 (1958).

4. H.M. Schmidt and J.F. Arens, Rec. Trav. Chim., 86, 1138 (1967).

5. H. Gilman, A.G. Brook, and L. Miller, J. Am. Chem. Soc., 75, 4531 (1953).

6. E. J. Corey and H. A. Kirst, Tetrahedron Letters, 5041 (1968).

7. J. T. Edmonds and Harold W. Hill, U.S. Patent 3, 354, 129 (Philips Petroleum).

8. P.E. Fanta, Chem. Rev., 64, 613 (1964).

9. F. Mathez and J. Bensoam, Tetrahedron, 27, 3965 (1971). 
6

b

$b$

b

$b$

$b$

b

b

b

$b$

6

6 


\section{REFERENCES (SYNTHESIS TECHNIQUES)}

(Fasil Analogue)

1. V.S. Chugunov, Izvest. Akad. Nauk. S. S.S.R., Otde1, Khim. Nauk. , 1960. Chem. Abst. 54, 24482e.

2. V. Bazant and M. Cerny, Collect. Czech. Chem. Comm. 39(7), $1880-4$ (1974).

3. V. Bazant and M. Cerny, Collect. Czech. Chem. Comm. 39(7), 1735-9 (1974).

4. C. L. Smith and R. Gooden, J. Organomet. Chem. 81(1), 33-40 (1974).

5. T. Takiguchi, J. Am. Chem. Soc., 81, 2359 (1959).

6. H. Anderson, J. Am. Chem. Soc., 73, 5802 (1951).

7. L. W. Breed, R. G. Elliott, and J. C. Wiley, Jr., J. Organomet. Chem. 31, 179 (1971).

8. E. L. Morehouse and D. L. Bailey, U.S. Patent 3,133,110 (Union Carbide Corp.) (1964), Chem. Abst. 61, P 18934. 

APPENDIX

EXPERIMENTAL PROCEDURES

DERIVATIVES OF ACYL FLOURIDE-TERMINATED

PERF LOUROA IKYLENE OXIDE

Preparation of $\mathrm{R}_{\mathrm{F}}$ (II $\left.\mathrm{O}-\mathrm{Br}\right)_{2}, \mathrm{XI}$

To $2.5 \mathrm{~g}$ of magnesium turnings covered with $200 \mathrm{ml}$ ether was added $24 \mathrm{~g}$ of $\mathrm{p}$-dibromobenzene: The reaction was initiated with a small amount of $\mathrm{I}_{2}$ and the mixture heated at reflux until most of the magnesium had disappeared (4 hours). To the mixture was added $30 \mathrm{~g}$ of the acyl fluoride $\mathrm{V}$ (PCR 6-EDAF) and reflux was continued for 4 hours. The reaction mixture was treated with dilute $\mathrm{HCl}$ and the solvent removed. From the milky oil was distilled $20 \mathrm{~g}$ of the expected product XI on a Kugelrohr apparatus at $200^{\circ} \mathrm{C}$ and 1 to $1.0 \times 10^{-3}$ torr. About $5 \mathrm{~g}$ of brown residue remained in the distillation flask which appeared to be a dimer XIV and possibly higher oligomers. The infrared spectrum of XIV (Figure 12) shows splitting of the aromatic resonance at $\sim 6.3$ microns which is not observed in the spectrum of XI (Figure 11), indicating two types of aromatic rings in the compound.

An elemental analysis of XI was obtained as follows: C, 27.09;

$\mathrm{H}, 0.62 ; \mathrm{Br}, 8.51 ; \mathrm{F}, 53.58$. The calculated analysis for $\mathrm{C}_{41} \mathrm{H}_{8} \mathrm{Br}_{2} \mathrm{~F}_{54} \mathrm{O}_{10}$ is: $\mathrm{C}, 26.6 ; \mathrm{H}, 0.43 ; \mathrm{Br}, 8.65 ; \mathrm{F}, 55.2$.

Attempt to Copolymerize V and Diphenyl Ether by the Friedel-Crafts Reaction

The acyl filuoride, V, $(5.0 \mathrm{~g})$ was dissolved in Freon TF with $1.0 \mathrm{~g}$ of $\mathrm{SbF}_{5}$. To this was added $0.32 \mathrm{~g}$ of diphenyl ether. The solution turned black on addition of the ether. The mixture was stirred several hours and then worked up with water. The infrared spectrum of the residue showed only the carboxylic acid present. 
Numerous variations of this reaction were attempted with different solvents and reaction conditions. Without exception, they were all unsuccessful.

Preparation of An Acetylene-terminated Amide Derivative VII

To a solution of $25 \mathrm{~g}$ of the acyl fluoride $\mathrm{V}$ in $300 \mathrm{ml}$ of anhydrous ether were added $0.26 \mathrm{~g} \mathrm{~N}$-methylaniline and $4.6 \mathrm{~g} \mathrm{3-aminophenylacetylene.}$ The solution was stirred 16 hours and then worked up by washing with $5 \%$ $\mathrm{HCl}$, saturated $\mathrm{NaHCO}_{3}$, and water. The ether was dried over $\mathrm{Na}_{2} \mathrm{SO}_{4}$ and the solvent removed.

Several samples of the oil were cured at $200-210^{\circ} \mathrm{C}$ for times ranging from 20 minutes to 80 minutes. The samples cured to rather hard resins. They were less brittle, however, than those made with amino-phenylacetylene alone without $\mathrm{N}$-methylaniline terminal groups. All samples, however, failed the hydrolysis test.

Attempted Preparation of Phenylacetylene Terminated Perflouroalkylene Oxide VIII

The Grignard of m-bromo(trimethysilylethynyl)benzene was prepared by reaction of the bromo compound with activated $\mathrm{Mg}$ powder (prepared from $\mathrm{MgCl}_{2}$ and $\mathrm{K}$ ) in THF. A stoichiometric amount of the acyl flouride $\mathrm{V}$ was added and the solution was heated at reflux for 6 hours. The solution was then treated with dilute $\mathrm{HCl}$, extracted with $\mathrm{CH}_{2} \mathrm{Cl}_{2}$, and the solvent removed. The infrared spectrum of the residue indicated the presence of a considerable amount of the carboxylic acid in addition to the expected ketone.

The trimethylsilyethinyl terminated compound was purified by column chromatography on silica gel. The compound was insoluble in the ethanol-water- $\mathrm{AgNO}_{3}$ solution used to hydrolyze off the trimethylsilyl group, so methyl ethyl ketone was added to bring the material into solution. The solution was stirred for 4 hours with mild heating; however, none of the precipitate which would have normally indicated silver acetylide formation was formed. The solution was treated with $\mathrm{NaCN}$, the solvents partially removed, and the aqueous solution extracted with $\mathrm{CH}_{2} \mathrm{Cl}_{2}$. Only a small 
fraction of the original material was recovered and it appeared to contain very little - if any - terminal acetylene function.

Several other approaches were taken to hydrolyze the trimethylsilyl group. All were unsuccessful in producing the desired product, mainly due to the difficulties in workup. It was initially hoped that the hydrolysis step could be bypassed; however, a DSC spectrum of the trimethylsilyl-terminated compound did not show any exotherms due to acetylene polymerization.

\section{Bromination of OS-124 Pentaphenylene Oxide}

To 0.5 mole of OS-124 dissolved in $700 \mathrm{ml} \mathrm{CCl}_{4}$ was added $0.1 \mathrm{~g}$ of iron powder and 2 drops water. Bromine $(1.75$ mole) was added with stirring over $1 / 2$ hour with considerable evolution of hydrogen bromide. The reaction was allowed to stand 16 hours at room temperature and then the reaction mixture was washed with sodium bicarbonate solution and then with water. The solvent was removed and the viscous oil dried at $150^{\circ} \mathrm{C}$ and $40 \mathrm{microns}$. Elemental analysis was as follows: C, 55.56; H, 3.02; Br, 34.43. This corresponds to 2.8 bromine atoms per pentaphenylene oxide molecule.

Preparation of 4, 4'-Biphenyl Perfluoroalkylene Oxide Polymer XIII

The di-Grignard reagent of 4, 4'-dibromobiphenyl was prepared from 10 mmoles of $4,4^{\prime}$-dibromobiphenyl and 20 mmoles of 100 mesh magnesium powder in $150 \mathrm{ml}$ of THF. All of the magnesium was consumed after 4 hours of reflux. Then, 9.5 mmoles of the acyl fluoride $V$ was added over 45 minutes to the refluxing solution. The mixture was further stirred 36 hours at room temperature. A small amount of $\mathrm{Br}_{2}$ was then added to ensure that any biphenyl terminal groups on the polymer chain would contain bromine atoms and, therefore, could be further reacted later if need be. The solution was poured into dilute $\mathrm{HCl}$, which resulted in the precipitation of a semisolid mass; this was separated and washed with water. Heating the residue for 1 hour at $200^{\circ} \mathrm{C}$ and 0.05 torr in the kugelrohr apparatus removed any low molecular weight impurities. The infrared spectrum of the solid indicated that the desired ketone had formed and that only a relatively small amount of free acid groups were present. Heating the material in an oven at $250^{\circ} \mathrm{C}$ resulted in fused, brittle glassy product. 
Synthesis of Acetylene-terminated Pentaphenlyene Oxide IX

To a solution of $6.8 \mathrm{~g}$ of tribrominated pentaphenylene oxide in $100 \mathrm{ml}$ ether, under argon, was added $7 \mathrm{ml}$ of fresh butyllithium (1.6 M). A white precipitate formed almost immediately and the reaction mixture was stirred for 45 minutes at room temperature. On addition of $5 \mathrm{~g}$ of acyl fluoride $\mathrm{V}$, an immediate reaction took place. The slightly pink solution was stirred 36 hours at room temperature. Treatment with dilute $\mathrm{HCl}$, extraction with $\mathrm{CH}_{2} \mathrm{Cl}_{2}$, and evaporation of the solvent produced an oily residue. The residue was chromatographed on silica gel; excess pentaphenylene oxide came off first on eluting with benzene, followed by the desired ketone on eluting with $\mathrm{CH}_{2} \mathrm{Cl}_{2}$, - ethanol.

The ketone $(4 \mathrm{~g})$ was dissolved in $20 \mathrm{ml}$ of $\mathrm{THF}$ and 4 equivalents of butyllithium was added. The solution was stirred 1-1/2 hours at room temperature, then treated with 2 equivalents of perfluorodecanoyl fluoride, followed by excess acetyl chloride. The reaction was worked up with dilute acid and the solvent removed. The iNMR spectrum of the product showed the presence of the methyl in the acetyl group.

The above product was dissolved in $\mathrm{POCl}_{3}$ and treated with excess $\mathrm{PCl}_{5}$ for 2 hours at $90^{\circ} \mathrm{C}$. The $\mathrm{POCl}_{3}$ was removed by vacuum distillation and excess $\mathrm{PCl}_{5}$ was sublimed out of the gummy residue, which was taken up in THF-t-butanol without further purification. An excess of potassium $t$-butoxide was added to the solution, which was then refluxed for 4 hours. The solvent was removed and the residue washed with water.

The infrared spectrum of the black gummy residue indicated a mixture of products present. It was impossible to tell how much, if any, acetyleneterminated material was present by normal means. A DSC (Figure 13) was taken of the material, and indicated an exotherm centered at $200^{\circ} \mathrm{C}$. A sample cured at $225^{\circ}$ for 4 hours had the appearance of a brittle black glass.

Preparation of Diphenyl Sulfide Linked Perfluoroalkylene Oxide Polymer XII

The bromophenyl-terminated monomer XI (4.6 g) was dissolved in NMP-benzene. To this was added $0.85 \mathrm{~g}$ of $\mathrm{Na}_{2} \mathrm{~S} \cdot 9 \mathrm{H}_{2} \mathrm{O}$, which caused the mixture to turn bright red. The solution was heated to reflux and the benzene and water were distilled off. 


\section{I \\ $c$ \\ c}

PART NO. 900326

(1IVDID INSTRUTMENTS

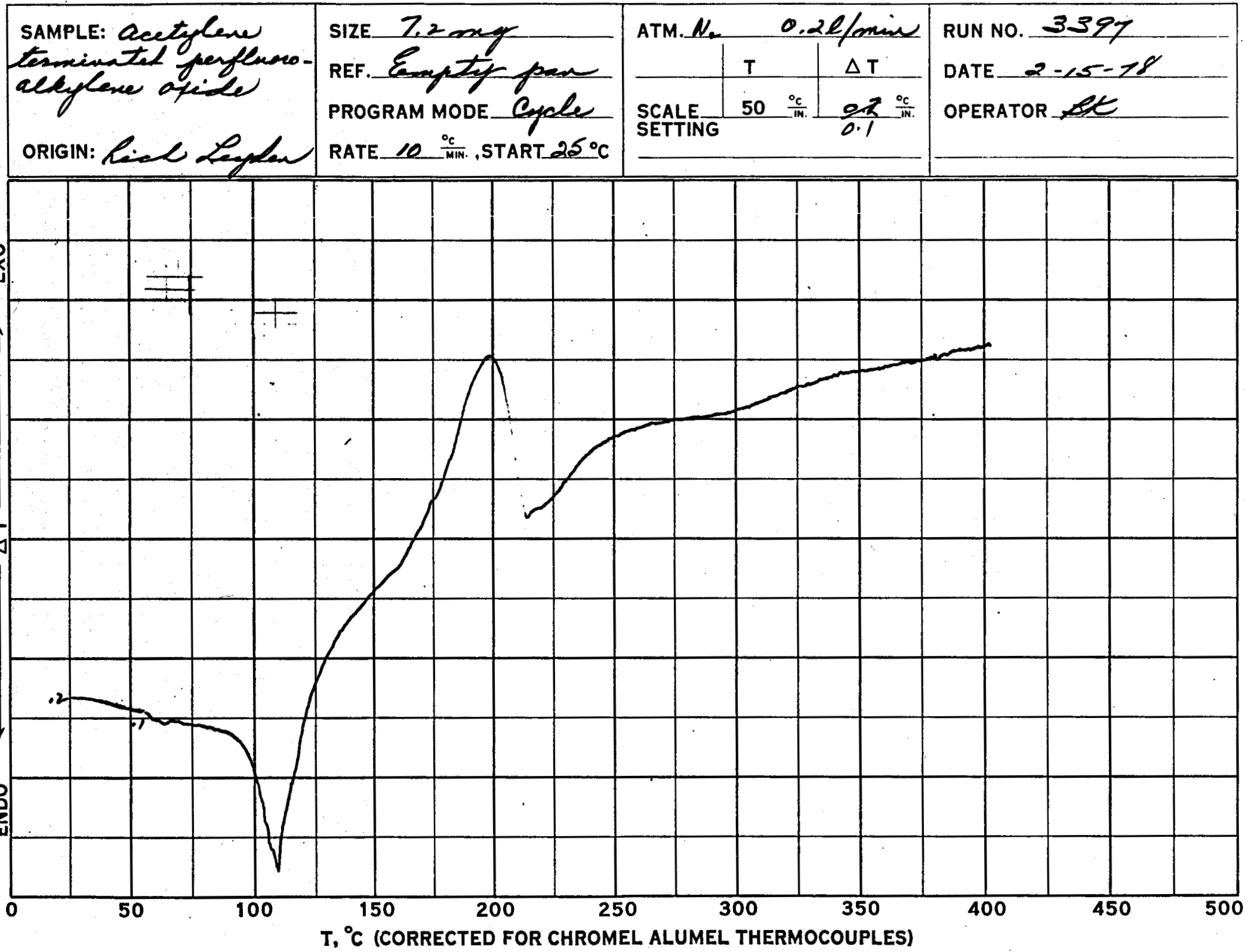

Figure 13. DSC on Compound IX. 
A catalytic amount of copper $(30 \mathrm{mg})$ was added and the reaction mixture was heated at reflux for 16 hours. The product was obtained by precipitation with water; it was a mixture of an oily phase and hard, black resinous material. The infrared spectrum of the oil indicated that it contained perfluoroalkylene oxide, but no carbonyl group.

In a separate experiment, the red product obtained after the initial heating of the reaction mixture at low temperature was isolated by removal of the solvent and found to be a homogeneous, hard, resinous material.

Reaction of XI With Disodium Resorcinate

To $0.48 \mathrm{~g}$ of resorcinol, in freshly distilled DMSO, was added 2 molar equivalents of $\mathrm{NaH}$. The mixture was briefly stirred and then $10 \mathrm{~g}$ of $\mathrm{XI}$ was added. The solution was heated at reflux overnight and then the solvent was partially removed. A small amount of a heavy liquid phase separated out of the collected distillate. Infrared analys is of the liguid showed it to be perfluoroalkylene oxide without the acyl group. Treatment of the residue with water resulted in the isolation of a brown, infusible solid.

\section{Attempted Polymerization by Copper Catalyzed Coupling of XI}

A $5 \mathrm{~g}$ sample of XI and $1 \mathrm{~g}$ of $\mathrm{Cu}$ powder were heated to $250^{\circ} \mathrm{C}$ for 16 hours. There appeared to be no reaction, so $10 \mathrm{ml}$ of pyridine and $\mathrm{N}$-methylpyrrolidinone (NMP) were added and the mixture was heated at reflux for several more hours. Again there appeared to be no reaction, so the pyridine and NMP were removed by distillation and the residue was heated to $290^{\circ} \mathrm{C}$. The starting material was recovered; it had darkened but was otherwise unchanged.

\section{Attempted Fluorination of the Carbonyl Groups of XI}

To $10 \mathrm{ml}$ of $\mathrm{CH}_{2} \mathrm{Cl}_{2}$ cooled to below $0^{\circ} \mathrm{C}$ was added $1.8 \mathrm{~g} \mathrm{MoF}_{6}$. A stream of $\mathrm{BF}_{3}$ was bubbled through for several minutes, then $10 \mathrm{~g}$ of $\mathrm{XI}$ dissolved in $\mathrm{CH}_{2} \mathrm{Cl}_{2}$ was added with stirring. The mixture was allowed to warm to room temperature over several hours. Sodium fluoride and alumina were added to the mixture, which was then filtered and the solvent was removed. The infrared spectrum of the recovered oil indicated that there had been no reaction. 
Butadiyne-containing Perfluoroalkylene Oxide Oligomers

Experiment J1580-86 - Model polymer not containing butadiyne

To a solution of 1,3-di(3-iodophenoxy)benzene (4.0 grams, 0.0077 mole) in anhydrous ether $(20 \mathrm{ml})$ under argon, butyllithium $(10 \mathrm{ml}$ or 0.016 mole in hexane) was added to the flask via a syringe inserted through a septem. The reaction mixture was cooled. More ether $(40 \mathrm{ml})$ was added and the perfluoroalkylene oxide acyl fluoride $V$ (mol wt 2000, 15, 39 grams, 0.0077 mole) was added by means of the syringe inserted through the septum. The solution was stirred for 16 hours, hydrolyzed and extracted with chloroform. The chloroform-insoluble portion yielded $10 \mathrm{grams}$ of a resinous product, which did not melt up to a temperature of $275^{\circ} \mathrm{C}$. The chloroformsoluble portion yielded about 4 grams of an oil which formed a skin on standing.

Experiment J1580-95

To a solution of $1,3-\operatorname{di}(3$-iodophenoxy)benzene $(5.0$ grams, 0.0096 mole) and 1,4-di(3-iodophenyl)butadiyne (1.09 grams, 0.0024 mole) in dry ether $(150 \mathrm{ml})$, butyllithium $(15 \mathrm{ml}, 0.0245$ mole in hexane) was added under argon. Then the perfluoroalkylene oxide acyl fluoride V (mol wt 2000, 24.0 grams, 0.0120 mole) was added dropwise under argon. The mixture was triturated with water and extracted with chloroform. The product consisted of an insoluble powder (14.9 grams) and an oil (9.0 grams). The powder could be molded into a pellet at $250^{\circ} \mathrm{C}$.

Experiment J1580-99

This experiment was a repeat of Experiment J1580-95, except that the molar ratio of 1,3-di(3-iodophenoxy)benzene to 1,4-di(3-iodopheny1)butadiyne was $5: 1$ instead of $4: 1$. Again, the reaction product could be separated by chloroform extraction into an oil and a solid. An oil was obtained as one of the products, even when the ether was freshly distilled from calcium hydride to rigorously exclude water (J2324-9). It is noteworthy that tetrahydrofuran as a reaction solvent yielded only an oily product. 